\title{
Geologia da Faixa Eclogítica de Forquilha, Domínio Ceará Central, noroeste da Província Borborema
}

\author{
Geology of the Forquilha Eclogite Zone, Ceará Central Domain, \\ northwestern Borborema Province
}

\section{Matheus Fernando Ancelmi ${ }^{1,2 *}$, Ticiano José Saraiva dos Santos ${ }^{2}$, Rafael Augusto Reginato ${ }^{3}$, Wagner da Silva Amaral ${ }^{4}$, Lena Virgínia Soares Monteiro ${ }^{5}$}

RESUMO: A partir de mapeamento geológico em escala de detalhe, 1:10.000, e estudo petrográfico sistemático foram caracterizados o modo de ocorrência, a distribuiçấo e as associaçóes minerais do retroeclogito de Forquilha, que situa-se em uma faixa N-S ao longo de mais de $16 \mathrm{~km}$ na regiâo NW da Província Borborema. Tais rochas ocorrem como boudins em gnaisses orto- e paraderivados e, raramente, associados a rochas cálciosilicáticas. Esta associação compóe a Faixa Eclogítica de Forquilha, que estruturalmente está em contato tectônico de empurrão com metapelitos e corpos subordinados de rochas metacarbonáticas e metamáficas metamorfizadas entre condiçóes fácies granulito de alta pressáo e fácies anfibolito superior pertencentes ao Grupo Ceará. O retroeclogito mostra três principais estágios de retrometamorfismo representados pelas seguintes reaçôes: $\left.1^{\circ}\right)\left[\mathrm{Grt}+\mathrm{Cpx}+\mathrm{Qtz}+\mathrm{H}_{2} \mathrm{O} \rightarrow \mathrm{Pl}+\mathrm{Amp}\right]$ e $[\mathrm{Grt}+\mathrm{Cpx}+$ $\left.\left.\left.\mathrm{Rt}+\mathrm{Qtz}+\mathrm{H}_{2} \mathrm{O} \rightarrow \mathrm{Amp}+\mathrm{Ilm}+\mathrm{Pl}\right] ; 2^{\circ}\right)[\mathrm{Omp} \rightarrow \mathrm{Di}+\mathrm{Pl}] ; 3^{\circ}\right)[\mathrm{Grt}$ $\left.+\mathrm{Di}+\mathrm{Pl}+\mathrm{H}_{2} \mathrm{O} \rightarrow \mathrm{Amp}\right]$ e $\left[\mathrm{Grt}+\mathrm{Pl}+\mathrm{Qtz}+\mathrm{H}_{2} \mathrm{O} \rightarrow \mathrm{Grt}_{2}+\mathrm{Pl}(\mathrm{An})\right.$ + Amp], além de incipiente formação tardia de Fe-clorita e actinolita. $\mathrm{O}$ retrometamorfismo ocorreu de forma heterogênea nestes corpos, sendo mais intenso nas bordas devido à interação com fluidos metamórficos canalizados ao longo de zonas de cisalhamento durante o processo de exumação progressiva. A ocorrência de retroeclogito em Forquilha é importante para a contextualização da evolução tectônica da Província Borborema durante a formação do Gondwana Ocidental, uma vez que este litotipo pode representar uma zona de sutura neoproterozoica.

PALAVRAS-CHAVE: retroeclogito; Domínio Ceará Central; Província Borborema; Gondwana Oeste.

\begin{abstract}
The retrograded eclogites of the Forquilha area have been characterized based on detailed geological mapping and systematic petrography. These rocks occur as boudins enclosed into ortho- and paragneisses and rarely in calc-silicate rocks along more than $16 \mathrm{~km}$ in a N-S trend, defining the Forquilha Eclogite Zone, in the NW portion of the Borborema Province. This zone is in tectonic contact with rocks of the Ceara Group that dominantly comprises metapelites and subordinately metacarbonatic and metamafic rocks metamorphosed under high-pressure granulite and upper amphibolite facies conditions. The retrograded eclogites show three important stages of retrometamorphism that can be described by the following reactions: 10) $\left[\mathrm{Grt}+\mathrm{Cpx}+\mathrm{Qtz}+\mathrm{H}_{2} \mathrm{O} \rightarrow \mathrm{Pl}+\mathrm{Amp}\right]$ and $[\mathrm{Grt}+\mathrm{Cp} x+\mathrm{Rt}$ $\left.\left.\left.+\mathrm{Qtz}+\mathrm{H}_{2} \mathrm{O} \rightarrow \mathrm{Amp}+\mathrm{Ilm}+\mathrm{Pl}\right] ; 2^{\circ}\right)[\mathrm{Omp} \rightarrow \mathrm{Di}+\mathrm{Pl}] ; 3^{\circ}\right)[\mathrm{Grt}$ $\left.+\mathrm{Di}+\mathrm{Pl}+\mathrm{H}_{2} \mathrm{O} \rightarrow \mathrm{Amp}\right]$ and $\left[\mathrm{Grt}+\mathrm{Pl}+\mathrm{Qtz}+\mathrm{H}_{2} \mathrm{O} \rightarrow \mathrm{Grt}_{2}+\right.$ $P l(A n)+A m p]$, besides incipient late formation of Fe-chlorite and actinolite. The retrogressive metamorphism occurred heterogeneously on these metamafic bodies. It was more intensive at the boudin rims and obliterated the higher P-T mineral paragenesis due to intense structurally controlled interaction with metamorphic fluids during progressive exhumation. These occurrences of retrograded eclogites might record a Neoproterozoic suture zone and are important geological features to understand the tectonic evolution of the Ceara Central Domain during the West Gondwana formation.
\end{abstract}

KEYWORDS: retrograded eclogites; Ceará Central Domain; Borborema Province; West Gondwana.

\footnotetext{
${ }^{1}$ Programa de Pós-graduação em Geociências, Universidade Estadual de Campinas - UNICAMP, Campinas (SP), Brasil. E-mail: matheusancelmi@gmail.com ${ }^{2}$ Departamentos de Geologia e Recursos Naturais, Instituto de Geociências - UNICAMP, Campinas (SP), Brasil. E-mail: ticiano@ige.unicamp.br 3Petrobras, Rio de Janeiro (RJ), Brasil. E-mail: regnato@gmail.com ${ }^{4}$ Departamentos de Geologia, Universidade Federal do Ceará - UFC, Fortaleza (CE), Brasil. E-mail: wamaral@ufc.br IInstituto de Geociências, Universidade de São Paulo - USP, São Paulo (SP), Brasil. E-mail: lena.monteiro@usp.br *Autor correspondente

Manuscrito ID 28635. Recebido em: 22/08/2012. Aprovado em: 10/03/2013
} 


\section{INTRODUÇÃO}

Eclogitos possuem grande importância na caracterização do contexto geotectônico, pois comumente marcam porçôes de material oceânico e/ou continental subduzidos em profundidades litosféricas maiores de $50 \mathrm{~km}$, permitindo definir limites de terrenos envolvidos em convergência. Quando associadas a arcos magmáticos, sequências supracrustais acrescionárias e lascas ofiolíticas, estas rochas permitem delimitar zonas de paleossutura (Caby 2003, Song et al. 2006, Guillot et al. 2008, Sajeev et al. 2009).

No Brasil, existem extensas faixas de dobramentos pertencentes ao ciclo Brasiliano (ca. $600 \mathrm{Ma}$ ) resultantes da colagem de grandes massas cratônicas na formação do supercontinente Gondwana, no entanto, a presença de eclogito nestas regióes é pouco conhecida. Há apenas poucas descriçóes de retroeclogitos que preservam relíquias ou evidências de paragêneses de alta pressão. A primeira ocorrência foi descrita na regiáo de Pouso Alegre (MG), inserida no contexto geológico da Província Mantiqueira, onde corpos boudinados de dimensôes métricas inserem-se em paragnaisses de fácies granulito (Choudhuri et al. 1978). Posteriormente, outras ocorrências de retroeclogitos foram relatadas nesta mesma província por Campos Neto \& Caby (1999), Vilela (2000) e Reno et al. (2009).

$\mathrm{Na}$ Província Borborema são conhecidos os retroeclogitos de Bodocó e Floresta (PE) (Beurlen \& Villarroel 1990, Beurlen et al. 1992, Almeida et al. 1997), de outras localidades no contexto geológico do Domínio da Zona Transversal e associados a zonas de cisalhamento, que podem representar paleossuturas (Almeida et al. 2009a, 2009b). As demais ocorrências da província estão localizadas no Domínio Ceará Central, na região de Forquilha (CE) (Santos et al. 2009b) e de Itatira (CE) (Castro 2004, Garcia \& Arthaud 2004, Amaral \& Santos 2008).

O retroeclogito de Forquilha aflora a oeste do Arco Magmático de Santa Quitéria (Fetter et al., 2003) e é representado por rocha de composição máfica com associaçôes minerais e texturas de descompressão indicativas da desestabilização da paragênese mineral de fácies eclogito. As ocorrências destes metamorfitos de alta pressão definem uma faixa de rochas denominada de Faixa Eclogítica de Forquilha (FEF) (Santos et al. 2008b, 2009b, Amaral 2010, Amaral, Santos \& Wernick 2011). Dados termobarométricos indicam que estas rochas foram submetidas à pressão igual ou superior a $17 \mathrm{kbar}$ e temperatura em torno de $770^{\circ} \mathrm{C}$ (Santos et al., 2009b; Amaral, 2010).

Os retroeclogitos de Itatira, por sua vez, estão posicionados a leste do Arco Magmático de Santa Quitéria e mostram condiçóes de pressão e temperatura similares às ocorrências de Forquilha (Castro 2004, Garcia \& Arthaud 2004).
É devido à presença de retroeclogitos tanto a oeste quanto ao leste do Arco Magmático de Santa Quitéria, que a definição de uma suposta subdução oceânica para o desenvolvimento de um sistema de arco ainda é controversa. Santos et al. (2008b, 2009b) e Amaral (2010) defendem uma subdução para leste, ao passo que Castro (2004) para oeste.

Desta forma, a delimitação da FEF, assim como a individualização dos corpos de retroeclogitos, sua relação com as hospedeiras e a caracterização petrográfica desses litotipos, com ênfase nos corpos de retroeclogitos, constituíram o objetivo deste trabalho, que poderá embasar interpretaçóes sobre a evolução tectônica da FEF, sua relação com o Arco Magmático de Santa Quitéria, além de comparaçôes petrológicas e tectônicas com as ocorrências de Itatira. Para isto, foi realizado mapeamento de detalhe na escala de 1:10.000 que subsidia as informaçóes aqui apresentadas.

\section{ARCABOUÇO GEOLÓGICO REGIONAL}

A Província Borborema é caracterizada como um complexo mosaico de terrenos separados por falhas ou altos do embasamento (Almeida et al. 1981), resultado da convergência dos crátons São Luís-Oeste Africano, São FranciscoCongo e Amazônico, que estiveram envolvidos na amalgamação e consequente formação do Supercontinente Gondwana. Esta Província é subdividida em sete principais domínios geotectônicos (Brito Neves, Santos \& Van Schmus 2000) limitados por zonas de cisalhamento de escala continental (Vauchez et al. 1995). A área de estudo insere-se no contexto da porção noroeste da Província Borborema (Fig. 1), onde os domínios litoestruturais Médio Coreaú e Ceará Central são os blocos crustais separados pelo Lineamento Transbrasiliano.

\section{Domínio Médio Coreaú}

O Domínio Médio Coreaú situa-se a noroeste do Lineamento Transbrasiliano e é coberto, a sudoeste, por rochas sedimentares fanerozoicas da Bacia do Parnaíba (Fig. 1). A estratigrafia deste domínio constitui-se por:

- Embasamento Paleoproterozoico Inferior (2,36 2,29 Ga, U-Pb em zircão; Fetter et al. 2000, Santos et al. 2009a) representado pelo Complexo Granja, que inclui suítes tonalito-trondhjemito-granodiorito (TTG) juvenis provavelmente desenvolvidas em um sistema de arcos de ilhas, gnaisses de alto grau metamórfico (kinzigitos, khondalitos e migmatitos), anfibolitos, granulitos máficos, enderbitos e leucogranitos (Santos et al. 2001).

- Sequência metavulcanossedimentardo Paleoproterozoico Superior (Unidade Saquinho) que compreende 


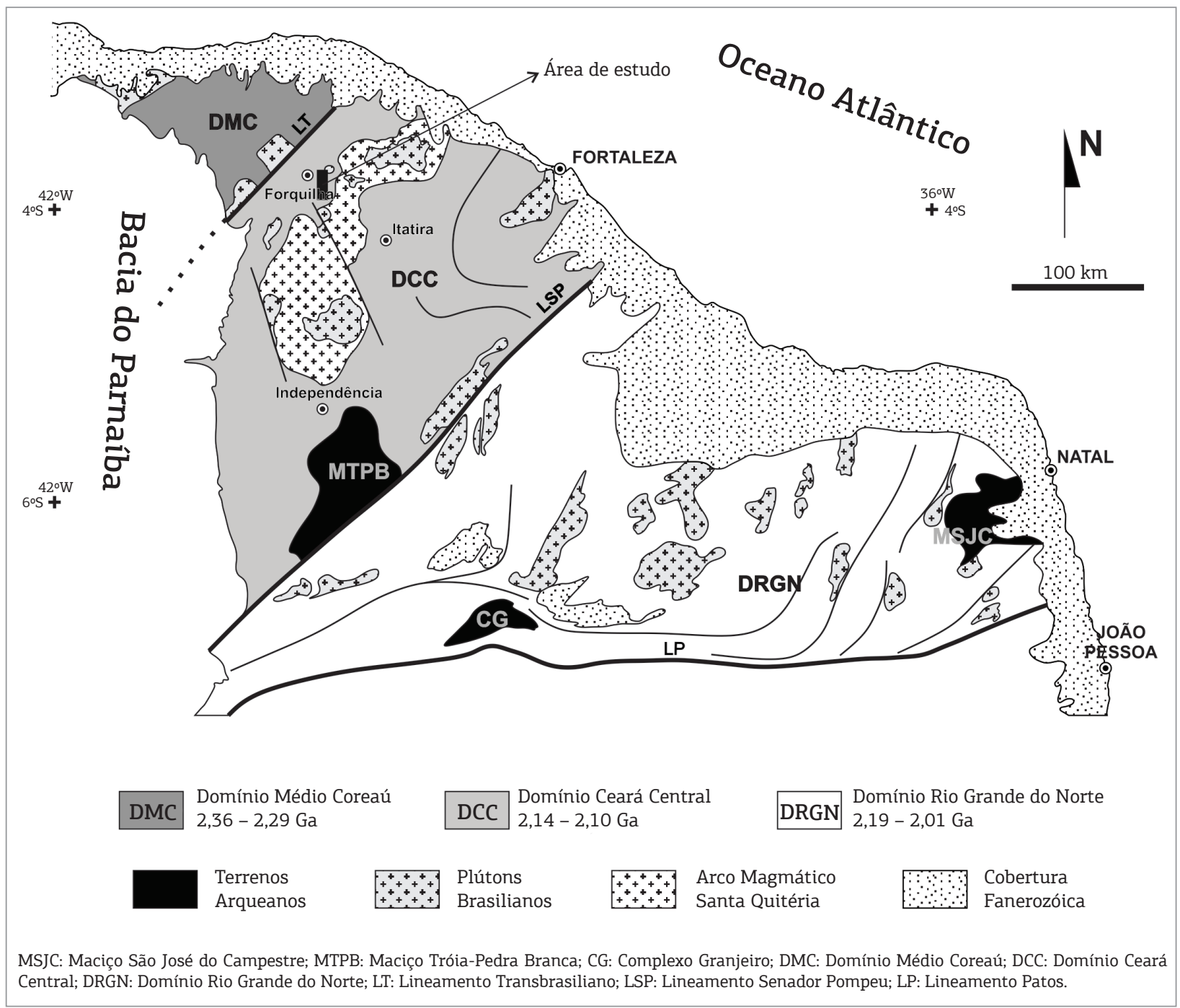

Figura 1. Mapa simplificado da porção setentrional da Província Borborema (adaptado de Fetter et al. 2000) mostrando seus principais blocos crustais e localização da área de estudo.

metatraquiandesito, metarriolito, metavulcanoclástica, metacarbonato e meta-arenito ferruginoso. Dados isotópicos U-Pb em zircão indicam idade de cristalização de 1,79 Ga para o metarriolito (Santos et al. 2002).

- Duas sequências metavulcanossedimentares neoproterozoicas (grupos Ubajara e Martinópole) constituídas por metapelito, meta-arcóseo, metagrauvaca, metaconglomerado e metacarbonato metamorfizados em condiçôes de fácies xisto verde a anfibolito. A idade máxima de sedimentação é estabelecida pelo zircão detrítico mais novo ca. $705 \mathrm{Ma}$ da Formação Goiabera, Grupo Martinópole (Araújo et al. 2012). Fetter et al. (2003) obtiveram também a idade de sedimentação datando um metarriolito concordante às rochas metassedimentares da sequência, e que apresentou a idade de cristalização U-Pb em zircão de $777 \pm 11 \mathrm{Ma}$.
Intrusões de plútons brasilianos (Chaval e Tucunduba) e pós-brasilianos (Meruoca e Mucambo) ocorreram dentro do intervalo entre 600 e $532 \mathrm{Ma}$ (Santos et al. 2008a).

- Sequência paleozoica (Grupo Jaíbaras) constituída por conglomerados, arenitos, siltitos e argilitos. Esta sequência é contida na bacia Jaíbaras, que é interpretada como resultante da reativação do Lineamento Transbrasiliano (Oliveira \& Mohriak 2003).

\section{Domínio Ceará Central}

O Domínio Ceará Central é limitado a oeste pelo Lineamento Transbrasiliano e a leste pelo Lineamento Senador Pompeu (Fig. 1). Este domínio é subdividido, segundo Arthaud et al. (2008), em quatro principais unidades lito-estruturais: 
Núcleo arqueano representado pelo maciço de TróiaPedra Branca que é limitado por zonas de cisalhamento (Caby \& Arthaud 1986) e constituído por ortognaisses de composição granodiorítica a tonalítica, um complexo máfico a ultramáfico e unidades vulcanossedimentar. Idades U-Pb convencional em zircão entre 2,7 - 2,8 Ga foram obtidas por Fetter (1999), ao passo que Silva et al. (2002) obtiveram idades U-Pb SHRIMP em zircáo em torno de 3,2 Ga em gnaisses desta unidade.

- Embasamento paleoproterozoico juvenil de 2,14 2,10 Ga (Fetter et al. 2000; Martins, Oliveira \& Lafon 2009) constituído por ortognaisse e migmatito com assinatura geoquímica de suítes TTG, e menores porçóes de paragnaisse e rocha metamáfica metamorfizadas em condiçôes de fácies anfibolito.

- Cobertura neoproterozoica representada pelo Grupo Ceará, composta por uma sequência dominantemente metapelítica com finas camadas de quartzito, lentes de metacalcário, finas camadas de rocha metavulcânica félsica e anfibolito. Arthaud et al. (2008) interpretaram os corpos de anfibolitos como possíveis derrames basálticos e/ou tufos, e as rochas paraderivadas como representantes de uma sequência de margem passiva depositada depois de $c a .750 \mathrm{Ma}$. No entanto, estudos recentes mostram que parte da sequência apresenta cristais de zircão detríticos com idade em torno de $660 \mathrm{Ma}$ (Ancelmi 2011, Araújo et al. 2012). Para Araújo et al. (2012), a distribuição das idades dos grãos de zircão detríticos das rochas metassedimentares do Grupo Martinópole (Domínio Médio Coreaú) se assemelha à distribuição obtida nas rochas do Grupo Ceará, levando-os a considerar que ambos grupos representam bacias correlacionáveis em um ambiente geotectônico de margem ativa, mas que foram metamorfizadas em níveis crustais distintos.

- Complexo dominantemente constituído por plutônicas félsicas de alto potássio (Complexo TamborilSanta Quitéria) com abundante quantidade de enclaves máficos. Possui bordas miloníticas e porçôes menos deformadas que coincidem com as injeções magmáticas mais novas (tardi-tectônicas). Em termos gerais, constitui-se por gabro, diorito, tonalito, granodiorito, monzogranito e diatexito com valores de $\varepsilon_{\mathrm{Nd}(\mathrm{T}=600 \mathrm{Ma})}$ que variam, predominantemente, de -13 a $+3,5$, e idades de cristalização entre 660 e $614 \mathrm{Ma}$, que são interpretadas como um complexo de arco magmático continental, denominado de Arco Magmático de Santa Quitéria (Fetter et al. 2003), relacionado ao ciclo Brasiliano/Pan-Africano.

\section{CONTEXTO GEOLÓGICO DA ÁREA DE ESTUDO}

A área estudada em escala de detalhe abrange $80 \mathrm{~km}^{2} \mathrm{e}$ situa-se $225 \mathrm{~km}$ a oeste de Fortaleza (CE). A partir do mapeamento $1: 10.000$, foram individualizados três faixas litoestruturais, limitadas por falhas de empurrão de expressão local, que são apresentadas de oeste para leste (Fig. 2):

- Faixa de gnaisses da Zona da Sillimanita (FZSill): paragnaisses com lentes de quartzito, rochas metamáficas e rocha cálcio-silicática.

- Faixa Eclogítica de Forquilha (FEF): compreende uma associação de augen gnaisse milonítico, paragnaisses com granada e sillimanita (e/ou cianita), biotita paragnaisse e ortognaisse migmatizado de composição granodiorítica, na qual encaixam-se lentes e boudins de retroeclogito e rochas cálcio-silicáticas.

- Faixa de gnaisses da Zona da Cianita (FZKy): paragnaisses com lentes de rocha metamáfica, mármore, rochas cálcio-silicáticas e quartzito.

As faixas possuem orientação N-S com planos de foliação $\left(\mathrm{S}_{\mathrm{n}}\right)$ que mergulham para E-SE. A estruturação é balizada por um sistema de rampas de empurrão, que se iniciam na borda oeste do Arco Magmático de Santa Quitéria, e são marcadas por planos de foliação milonítica com mergulho de baixo ângulo (média $=98 / 30)$ e lineação de estiramento mineral $\left(\mathrm{L}_{\mathrm{x}}\right)$ definida por sillimanita, cianita, quartzo e biotita com caimento para leste (média $=98 / 30$ ). A medida que se avança para oeste, a intensidade de mergulho da foliação $\left(S_{n}\right)$ e dos planos de empurrão aumenta, exibindo mergulho de médio a alto ângulo (média $=105 / 68$ ) e lineação de estiramento mineral com caimento com atitude média de 180/10.

A orientação da lineação de estiramento mineral associada aos indicadores cinemáticos, definidos principalmente por porfiroclastos de álcali-feldspatos e estruturas S-C, indicam movimento das falhas de empurrão de topo para W-NW. Curtas zonas transcorrentes destrais e sinistrais de direção N-S e NNE-SSW possuem planos de alto ângulo $\left(\mathrm{S}_{\mathrm{n}+1}\right)$ e lineação de estiramento mineral, marcada principalmente por quartzo e muscovita, de caráter direcional $\left(\mathrm{L}_{\mathrm{x}+1}\right)$. Esta foliação, por vezes, transpóe a foliação $\mathrm{S}_{\mathrm{n}} \mathrm{e}$ caracteriza um evento estrutural posterior, mas de natureza progressiva. Estas faixas são intrudidas pelo granito Serra do Barriga de caráter pós-tectônico que possui idade U-Pb em monazita de $522 \mathrm{Ma}$ (Mattos 2005).

\section{Faixa de gnaisses da Zona da Sillimanita}

A FZSill é dominantemente composta por paragnaisses de coloração cinza, representados por sillimanita-biotita gnaisse e sillimanita-granada-biotita gnaisse (Fig. 3A). 


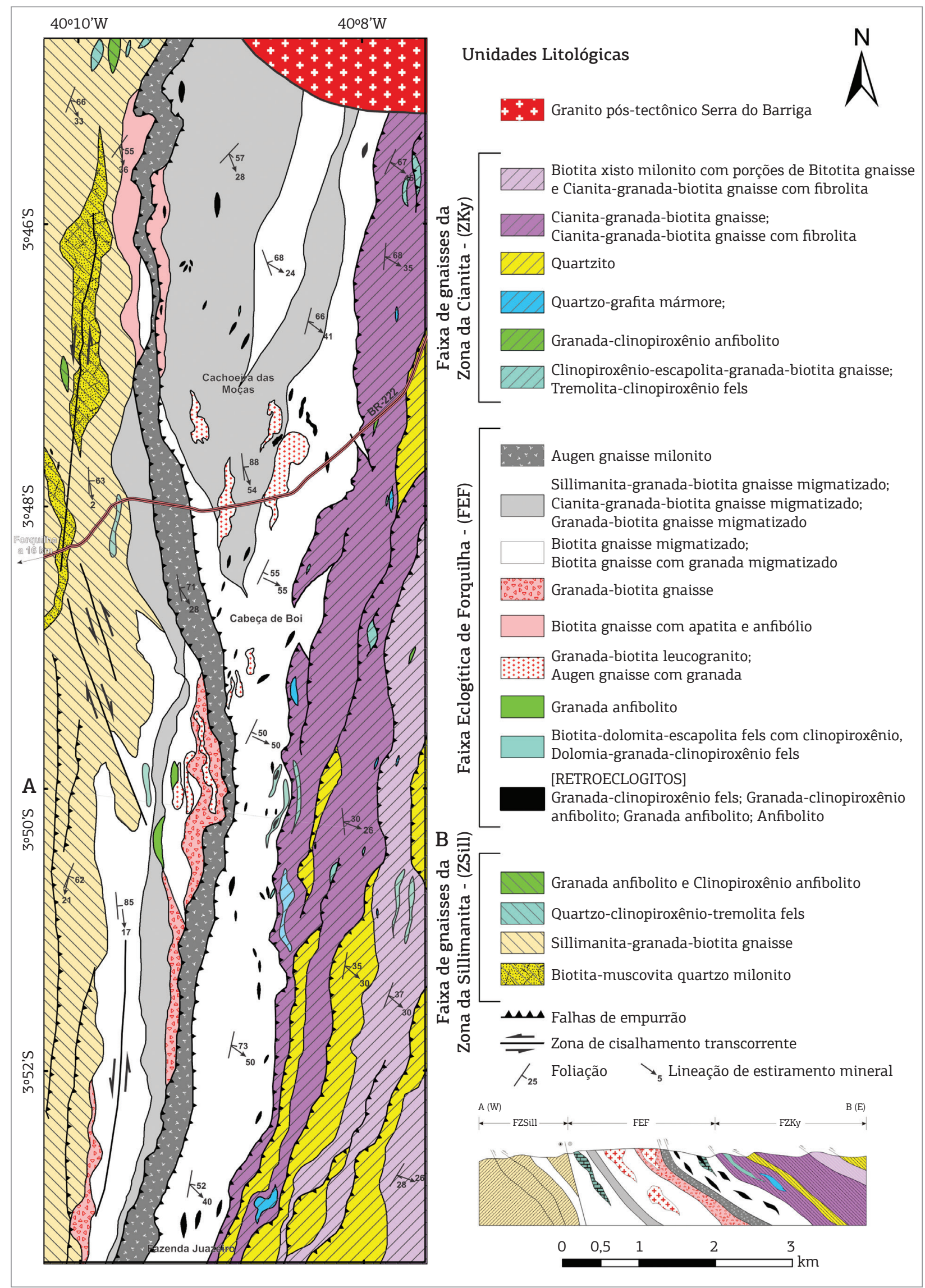

Figura 2. Mapa geológico de detalhe e perfil geológico esquemático de uma porção da Faixa Eclogítica de Forquilha. 
Essas rochas possuem cerca de $10 \%$ de sillimanita e entre 30 e 40\% de biotita idioblástica com intensa coloração avermelhada em lâmina delgada, o que caracteriza biotita rica em Ti (Fig. 3B). Quartzo (20 a 25\%), plagioclásio (10 a 15\%) e álcali-feldspato (10\%) constituem o restante da matriz da rocha, que inclui até $15 \%$ de poiquiloblastos de granada que alcançam diâmetro de até $8 \mathrm{~mm}$. A granada possui sombras de pressão assimétricas preenchidas por quartzo e biotita, o que aponta que a granada seja pré- a sin-tectônica em relação ao evento que promoveu a foliação $S_{n}$. As inclusôes na granada, por vezes rotacionadas, são predominantemente de quartzo, plagioclásio e biotita e são de tamanho e posição esparsa. O plagioclásio apresenta-se, via de regra, como cristais xenoblásticos saussuritizados e, por vezes, envolvidos por uma fina auréola de intercrescimento de quartzo e feldspato.

Destaca-se ainda o fato de que a FZSill, dentre as demais, é a mais afetada por falhas transcorrentes, ao longo das quais é comum a presença de muscovita resultante de metamorfismo dinâmico. Nas proximidades dessas curtas zonas transcorrentes a quantidade de muscovita é grande o suficiente para caracterizar um litotipo diferenciado, e assim individualizar uma unidade milonítica representada por biotita-muscovita-quartzo gnaisse milonítico, situada na porção norte da faixa (Fig. 2).

Dois corpos de rochas metamáficas, na forma de lentes de até $600 \mathrm{~m}$ de comprimento e de composição mineralógica diferenciada entre si, estão encaixados nos gnaisses paraderivados desta faixa (Fig. 4A). O primeiro, situado a norte, é representado por granada anfibolito, constituído por poiquiloblastos de granada (de até $7 \mathrm{~mm}$ ) rotacionados, com inclusões de plagioclásio, hornblenda, quartzo e titanita, e sombras de pressão assimétricas preenchidas por quartzo, em uma matriz constituída dominantemente por hornblenda subidioblástica $(65 \%)$, plagioclásio (20\%), quartzo (10\%) e resquícios de diopsídio metamórfico $(<1 \%)$, dispostos em textura nematoblástica (Figs. 4B e C). Subordinadamente, neste granada anfibolito, ocorrem calcita, Fe-clorita e titanita. O segundo corpo, na porção sul (Fig. 2), é constituído por hornblenda subidioblástica (50 a $60 \%$ ) e xenoblastos de diopsídio (20\%) que se apresentam em bandas paralelas e descontínuas caracterizando uma textura tipicamente nematoblástica. Nas bordas e nos planos de clivagem, o diopsídio é substituído por hornblenda e epídoto $(10 \%)$ (Figs. $4 \mathrm{D}$ e E) em uma típica reação retrógrada. Plagioclásio (10\%), quartzo $(<5 \%)$ e minerais acessórios, tais como titanita e ilmenita, são os demais constituintes.

Também encaixadas nos gnaisses têm-se lentes de rocha cálcio-silicática com dimensôes até $100 \mathrm{~m}$ de largura que são constituídas por clinopiroxênio cálcico (diopsídio), dolomita, calcita, quartzo, tremolita e titanita.

\section{Faixa Eclogítica de Forquilha}

A FEF constitui um conjunto de rochas que perfaz aproximadamente $40 \%$ da área mapeada. Esta faixa possui uma organização complexa e heterogênea englobando gnaisses para- e ortoderivados com diferentes graus de migmatização. Os migmatitos envolvem lentes de retroeclogito e rochas cálcio-silicáticas boudinadas em uma direção geral N-S.

Os gnaisses paraderivados são representados por cianita-granada-biotita gnaisse migmatizado e sillimanitagranada-biotita gnaisse migmatizado e estão localizados, principalmente, na porção setentrional da área. Essas rochas possuem notória variação na proporção dos minerais constituintes, caracterizando zonas mais ricas em
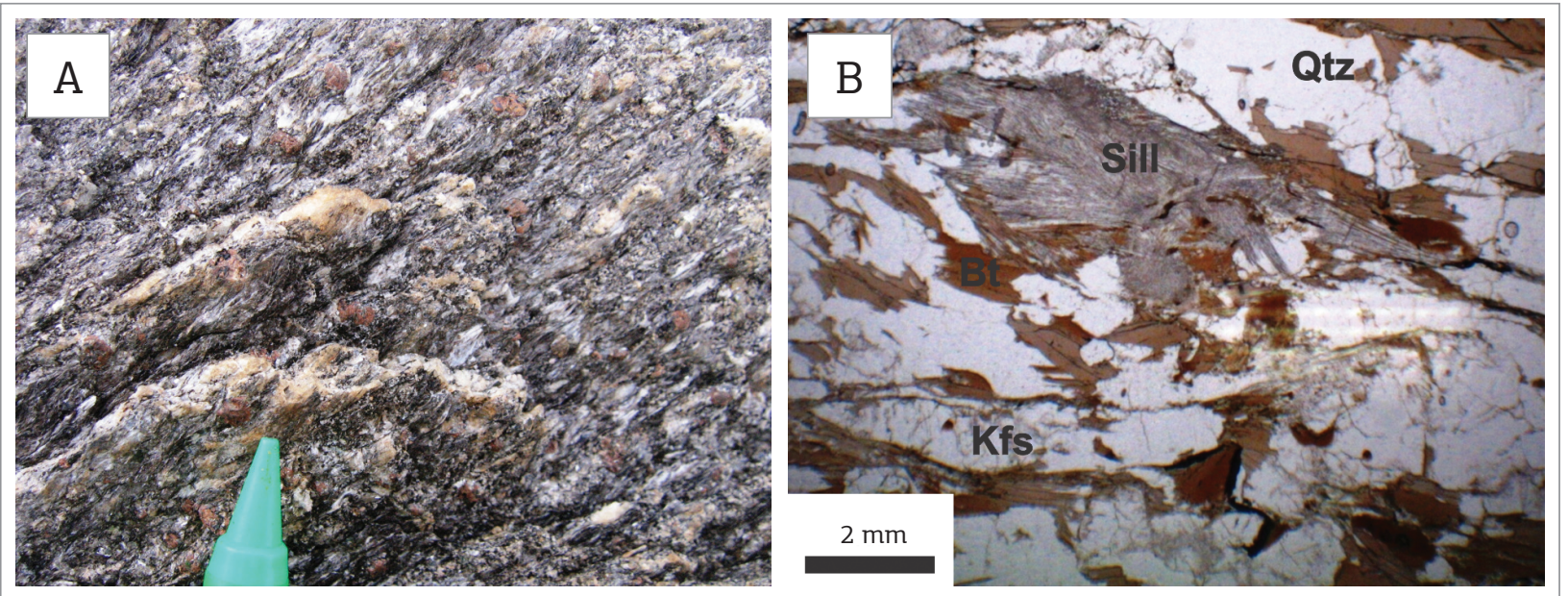

Figura 3. Gnaisse paraderivado da Faixa de gnaisses da Zona da Sillimanita. (A) Aspecto macroscópico de sillimanita-granada-biotita gnaisse. (B) Fotomicrografia mostrando parte da associação mineral da rocha que é constituída por Grt + Sill + Pl + Kfs + Bt + Qtz. 
quartzo-feldspato e outras mais ricas em minerais máficos, como gramada e biotita, e polimorfos de aluminossilicatos (sillimanita e cianita). Sillimanita-granada-biotita gnaisse (Figs. 5A e B) perfaz o maior volume desta unidade de gnaisses paraderivados, sendo as melhores exposiçóes na localidade Cabeça de Boi (Fig. 2).

Ao longo da FEF observa-se que a fusão parcial dos paragnaisses foi mais intensa em algumas porçóes, sendo possível diferenciar e estabelecer unidades litológicas de extensas áreas de rochas leucocráticas, cujos litotipos são granadabiotita gnaisse migmatizado, biotita-granada leucogranito e augen gnaisse com granada (Fig. 5C), sendo estes mais frequentes na região de Cachoeiras das Moças (Fig. 2).

$\mathrm{O}$ ortognaisse é representado por biotita gnaisse com anfibólio e apatita, fortemente migmatizado (Fig. 6A) e com limites gradacionais ou erráticos em relação aos paragnaisses, indicando que estes estejam interdigitados de forma complexa, exceto à unidade de augen gnaisse milonítico que possui seus limites estabelecidos por planos de empurrão. $\mathrm{O}$ augen gnaisse milonítico constitui uma faixa de direção N-S com espessura aparente de até $700 \mathrm{~m}$. São rochas composta por porfiroclastos de até $8 \mathrm{~cm}$ de álcali-feldspato (Fig. 6B), ocelares, imersos em matriz de granulação fina a média, constituída por biotita, quartzo, plagioclásio e menores porçôes de anfibólio e apatita dispostos em uma textura nematoblástica.

Rochas cálcio-silicáticas e retroeclogito estão encaixados nos gnaisses orto e paraderivados. As rochas cálcio-silicáticas localizam-se, em maior abundância, na porção central da área de estudo, e ocorrem como boudins maciços e homogêneos com cerca de $300 \mathrm{~m}$ de comprimento e $60 \mathrm{~m}$ de largura. Os litotipos representantes das rochas cálcio-silicáticas são dolomita-granada-clinopiroxênio gnaisse e biotitadolomita-escapolita fels com clinopiroxênio, e comumente estão próximas às ocorrências de retroeclogito. $\mathrm{O}$ retroeclogito ocorre como corpos boudinados de geometria lenticular e dimensóes que variam de 10 a $200 \mathrm{~m}$ de largura e 25 a $800 \mathrm{~m}$ de comprimento (Fig. 7A). As ocorrências estão sempre a leste da faixa de augen gnaisse milonítico (Fig. 2).

Ao longo de $16 \mathrm{~km}$ (N-S), foram individualizados mais de 40 corpos de retroeclogito encaixados em orto- e paragnaisses e, raramente, em rochas cálcio-silicáticas. Os litotipos
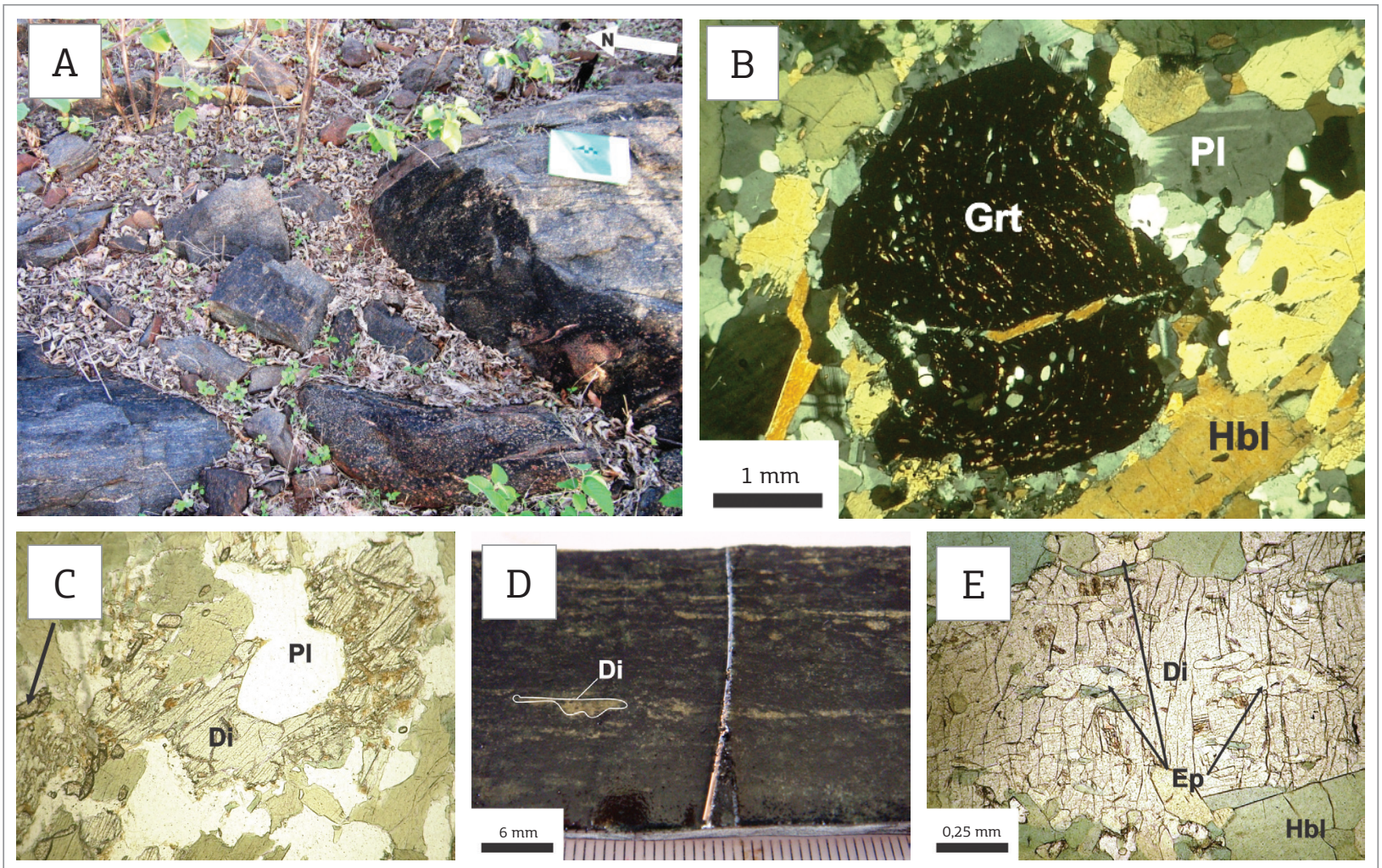

Figura 4. Rochas metamáficas encaixadas em paragnaisses da Faixa de gnaisses da Zona da Sillimanita. (A) Afloramento de granada anfibolito inserido na Faixa de gnaisses da Zona da Sillimanita. Foliação com atitude 170/68 e indicadores cinemáticos, como poiquiloblastos de granadas rotacionadas (vide B), indicam movimento de topo para W. As inclusões deste poiquiloblasto são de titanita, quartzo e anfibólio. (C) Destaque para os raros cristais de diopsídio presente na rocha. (D) Foto de detalhe de diopsídio anfibolito. Destaque para os cristais de diopsídio que se apresentam em bandas paralelas e descontínuas. (E) Fotomicrografia mostrando que o diopsídio é substituído em suas bordas e nos planos de clivagem por epídoto e hornblenda, em reação retrometamórfica. 
representantes desta unidade são anfibolitos com granada, granada anfibolitos, clinopiroxênio-granada anfibolitos e granada clinopiroxenitos (ou granada-clinopiroxênio fels). Em geral, são rochas verde acinzentado a verde escuro, com aspecto maciço. Alguns corpos apresentem uma marcante foliação gnáissica (Fig. 7B) ou um bandamento, este definido pela diferença de composição mineral, no qual ocorrem faixas mais ricas em anfibólio e plagioclásio, retrometamórficos, e outras mais ricas em granada e clinopiroxênio, que resguardam a paragênese de mais alta pressão (Fig. 7C). Normalmente, as porçóes isotrópicas, mais ricas em piroxênios situam-se na porção central dos boudins, ao passo que suas bordas, quanto mais foliadas mais enriquecidas em anfibólio são.

A exemplo de retroeclogitos encontrados em outras regiôes do planeta (Will \& Schmädicke 2001, Zhao et al. 2001, Brewer et al. 2003, Sartini-Rideout, Gilotti \&
McClelland 2009), os de Forquilha também possuem uma variação mineralógica e textural que se expressa, por vezes, em um mesmo corpo rochoso (boudin), devido ao processo retrometamórfico heterogêneo, em parte controlado pela infiltração de fluídos metamórficos ao longo de estruturas geradas no processo de exumação.

Granada clinopiroxenitos ou clinopiroxênio fels são descritos somente nas localidades de Cachoeira das Moças e Fazenda Juazeiro (Fig. 2). Tratam-se de rochas mesocráticas e que, por vezes, apresentam um leve bandamento. A granada ocorre como poiquiloblastos anédricos com dimensão média em torno de $1,5 \mathrm{~mm}$, podendo alcançar cerca de até $3 \mathrm{~mm}$ e com feiçôes do tipo atol (Figs. 8A e B), comumente encontradas em eclogitos (Bard 1985, Faryad, Klápová \& Nosál 2010). Análises semiquantitativas em microscópio eletrônico de varredura $(\mathrm{MEV})$ nestas rochas
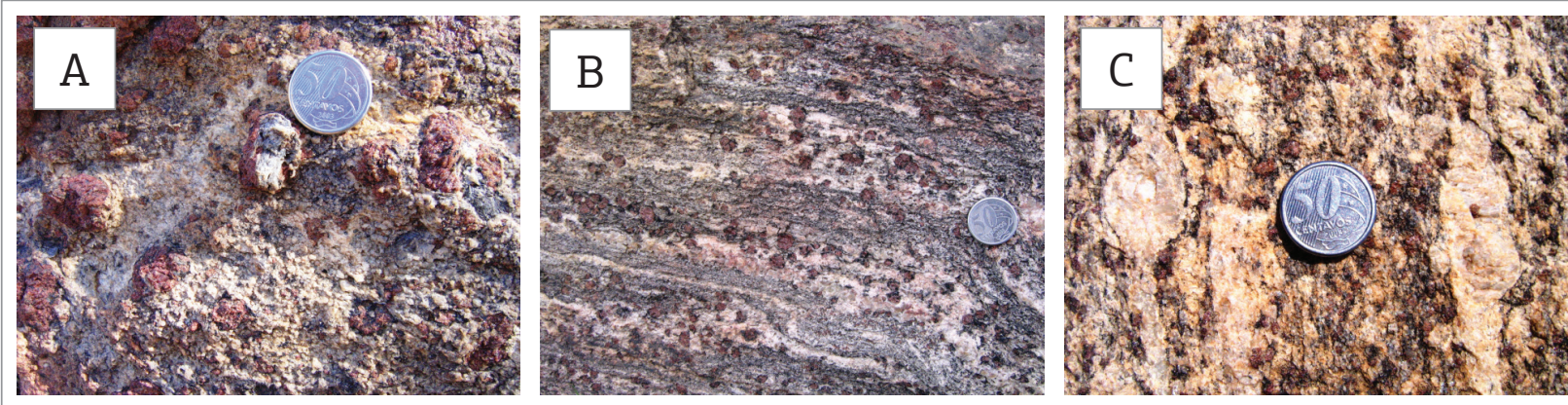

Figura 5. Paragnaisses encaixantes dos retroeclogitos. As principais ocorrências estão na localidade de Cachoeira das Moças. (A) Feição macroscópica de uma porção rica em aluminossilicatos e basicamente composta de poiquiloblastos de granada com inclusões de cianita alteradas para sillimanita branca em uma matriz dominantemente constituída de sillimanita escura, biotita e álcali-feldspato. (B) Foto de porção com leve migmatização e a ocorrência de porfiroblastos de granada junto às porções leucocráticas. (C) Porção fortemente migmatizada com presença de porfiroblastos de álcali-feldspato. As figuras (A), (B) e (C) mostram uma variação que ocorre em um perfil de aproximadamente $300 \mathrm{~m}$ e estabelecem um quadro evolutivo do processo de migmatização dos paragnaisses da Faixa Eclogítica de Forquilha.
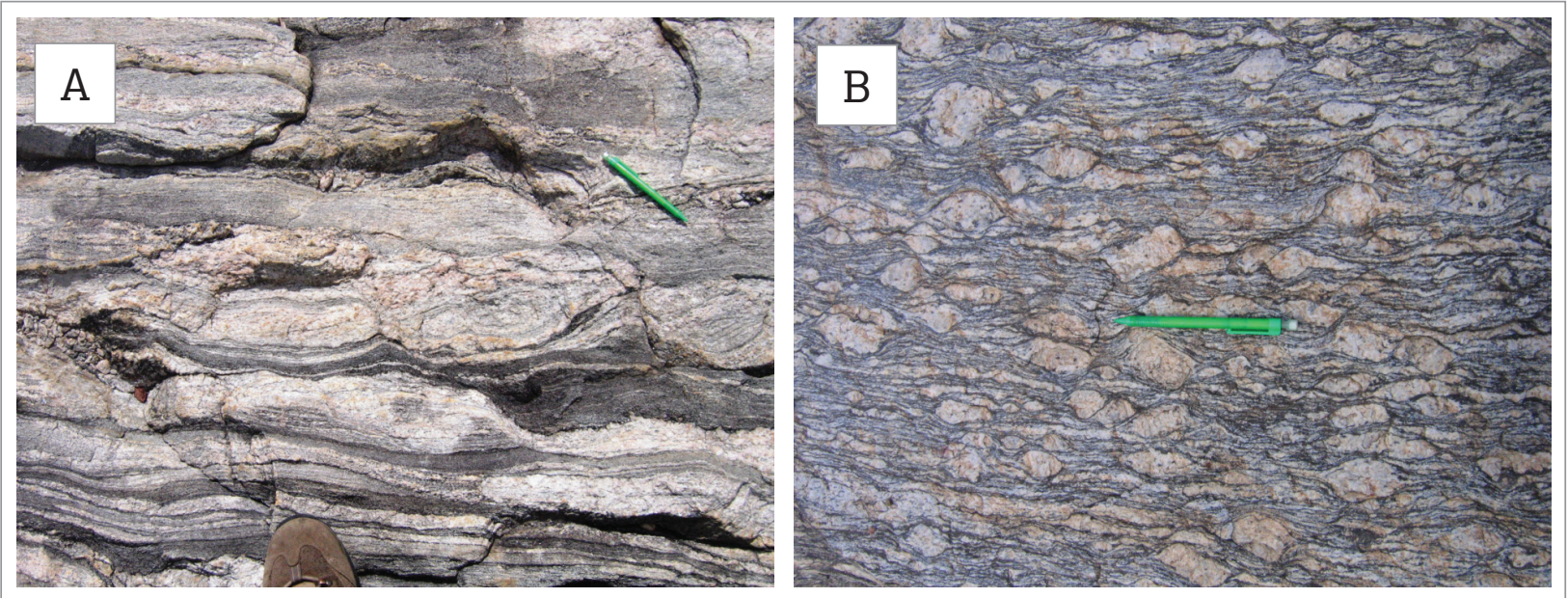

Figura 6. Ortognaisses da Faixa Eclogítica de Forquilha. (A) Biotita gnaisse migmatizado com anfibólio e apatita constitui uma unidade ortoderivada que também encaixa os retroeclogitos; (B) Augen gnaisse milonítico. Porfiroblastos de álcali-feldspato atingem dimensões de até $7 \mathrm{~cm}$. Os retroeclogitos estão sempre a leste desta unidade. 
revelam que a granada possui uma composição média estimada de almandina ( $\left.\mathrm{Alm}_{46,0-51}{ }_{1} \mathrm{Grs}_{23,0-29,0} \operatorname{Prp}_{19,5-24,4} \mathrm{Sp}_{0,8-1,7}\right)$, com enriquecimento da molécula piropo nas regióes centrais e nas bordas dos cristais, com a concomitante diminuição da molécula almandina e grossulária (Fig. 8C). Este zoneamento químico sugere mais de uma fase de blastese e pode também ser verificado pela maior concentração de inclusões nas porçôes centrais dos cristais em relação às suas bordas, definindo contornos retilíneos que podem representar limites de zonas de crescimento (Fig. 8C). Isto sugere um crescimento euédrico para a primeira geração de granada. As inclusôes são dominantemente de quartzo, hornblenda, clinopiroxênio, plagioclásio e rutilo, e, subordinadamente, de zircão, pirita, barita, allanita, safflorita $\left[(\mathrm{Co}, \mathrm{Ni}, \mathrm{Fe}) \mathrm{As}_{2}\right]$ e ouro.

A matriz do granada-clinopiroxênio fels é dominantemente constituída por finos simplectitos de diopsídio e plagioclásio (principalmente oligoclásio e andesina, com algumas ocorrências de albita). As vermículas de diopsídio e plagioclásio medem cerca de $30 \mu \mathrm{m}$ e podem representar pseudomorfos de onfacita (Fig. 9A). O anfibólio, quando presente, aparece em finas coronas envolvendo a granada ou substituindo vermículas de diopsídio nos simplectitos (Figs. 9B e D). O plagioclásio, além de estar presente nos simplectitos, encontra-se também como finas coronas, de espessuras de até $150 \mu \mathrm{m}$, envolvendo granada (Fig. 9C). Quartzo, apatita, rutilo são as principais fases acessórias.

Clinopiroxênio-granada anfibolito é o litotipo mais frequente e é encontrado praticamente em todos os corpos de norte a sul da área mapeada. Os poiquiloblastos de granada apresentam coronas de plagioclásio. Possuem forma subidioblástica e diâmetro de até $2,5 \mathrm{~mm}$ e os minerais inclusos são de clinopiroxênio, anfibólio, plagioclásio, quartzo, rutilo e titanita. A matriz é constituída por simplectitos grossos de clinopiroxênio e plagioclásio, no qual as vermículas possuem
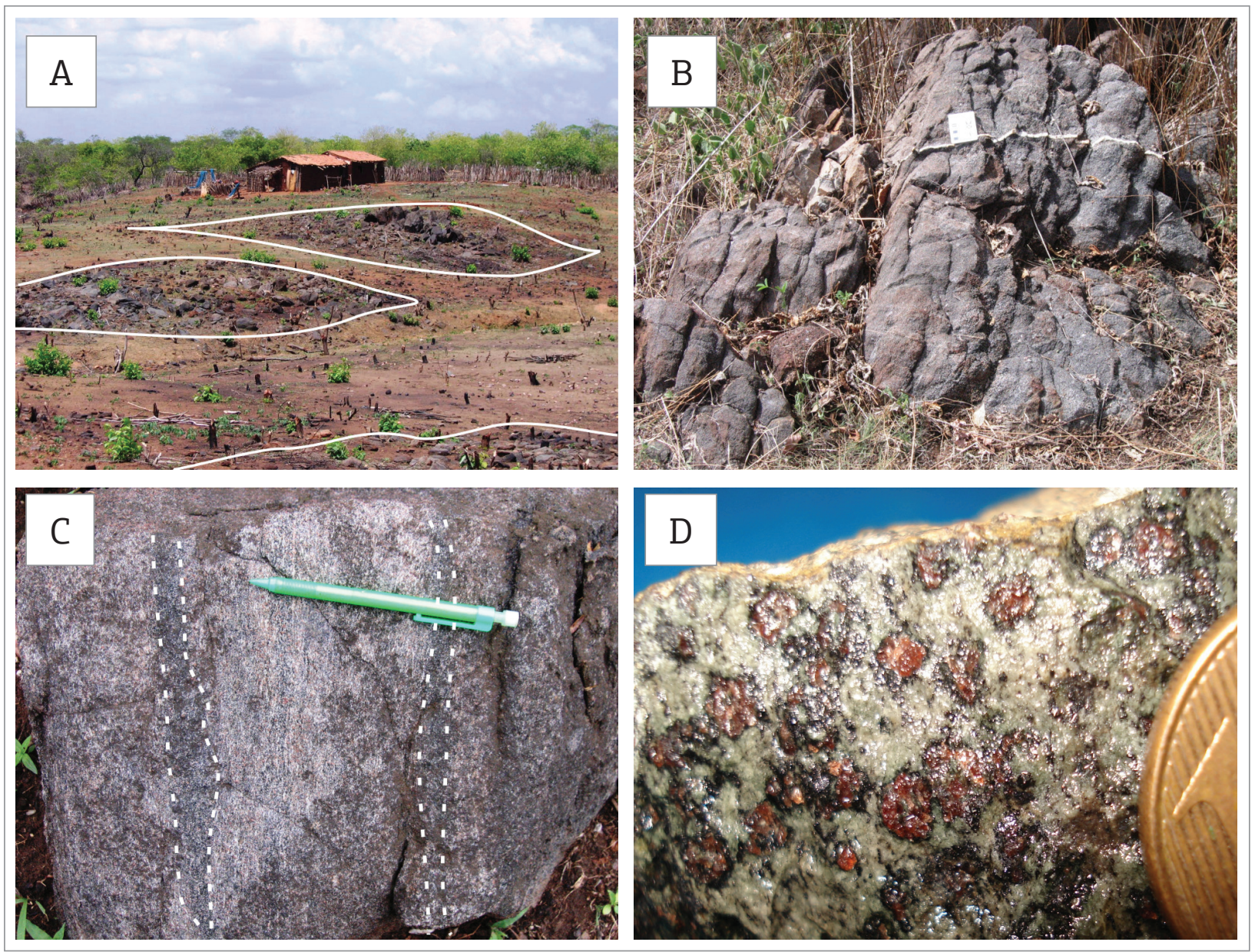

Figura 7. Aspectos macroscópicos do retroeclogito de Forquilha. (A) Forma de ocorrência do retroeclogito. Encaixados na forma de boudins em gnaisses orto- e paraderivados; (B) porção foliada de retroeclogito; (C) o retroeclogito, por vezes, apresenta faixas (destacado na figura por linhas tracejadas brancas) com paragênese retrometamórfica mais concentrada, onde há maior proporção de anfibólio e plagioclásio; (D) aspecto macroscópico de granada-clinopiroxênio fels da localidade de Fazenda Juazeiro. Granada envolvida por anfibólio em matriz esverdeada composta por simplectitos de diopsídio e plagioclásio. 

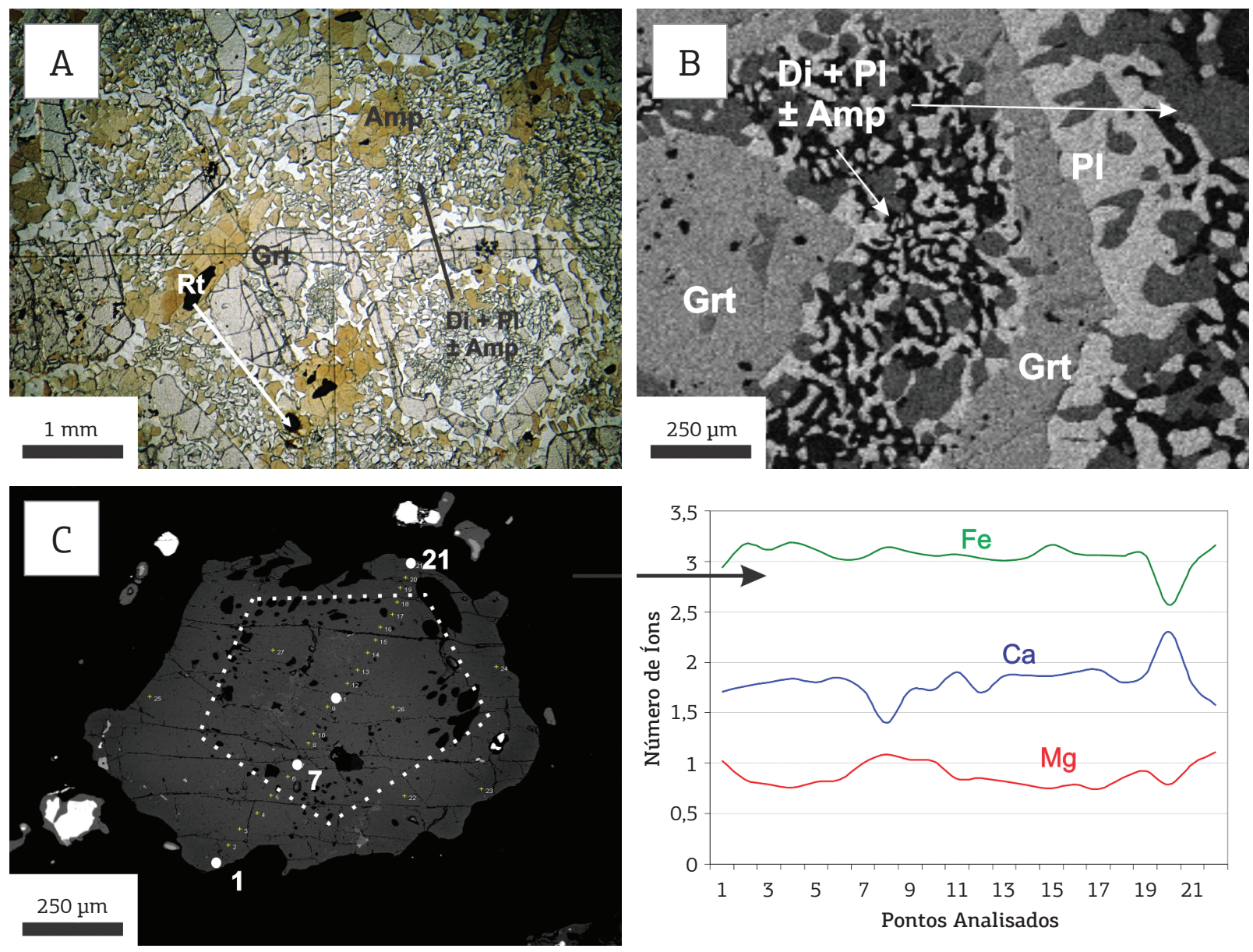

Figura 8. Aspectos microscópicos do retroeclogito de Forquilha. (A) Fotomicrografia de retroeclogito com granadas do tipo atol, onde mostra que simplectitos de diopsídio e plagioclásio ocorrem no interior e exterior das ilhas de granada; (B) a imagem em microscópio eletrônico de varredura ainda ressalta que estas ilhas de granadas, além de cercar simplectitos, abarcam em seu interior granada subeuédrica com inclusões de anfibólio, quartzo, plagioclásio; (C) imagem em microscópio eletrônico de varredura de poiquiloblasto xenomórfico de granada com inclusões de quartzo que desenham contorno de uma primeira blastese de granada. As análises semiquantitativas indicam enriquecimento de $\mathrm{Mg}$ na região central e borda.

entre 60 e $130 \mu \mathrm{m}$ de espessura e, por vezes, são obliteradas por anfibólio idioblástico a subidioblástico em textura nematoblástica (Figs. 10A e B). Também foram observadas texturas coroníticas de titanita em rutilo e ilmenita.

Granada anfibolitos e anfibolitos com granada são litotipos que ocorrem nas bordas dos corpos de retroeclogito e são porçôes que estiveram em contato direto com os gnaisses encaixantes. Possuem poiquiloblastos de granada com diâmetro próximo a $1,5 \mathrm{~mm}$ envoltos por espessa $(0,5-1,0 \mathrm{~mm})$ corona de plagioclásio. Há também granada subidioblástica, com diâmetro inferior a $0,5 \mathrm{~mm}$ e isenta de inclusóes e corona de plagioclásio, o que caracteriza uma segunda geração. A matriz é dominantemente constituída de anfibólio e plagioclásio, com raros resquícios de rutilo e vermículas de clinopiroxênio. Notase também que há uma maior concentração de ilmenita e titanita, que juntas chegam a constituir até $5 \%$ da rocha.

\section{Faixa de gnaisses da Zona da Cianita}

Esta faixa é dominantemente composta por cianitagranada-biotita gnaisse de coloração cinza e granulação que varia de média a grossa (Fig. 11A). A matriz gnáissica é constituída por quartzo ( $-20 \%)$, plagioclásio (5 a 10\%), álcali-feldspatos (15\%), biotita (25\%) e fases acessórias, tais como rutilo, ilmenita e apatita que chegam a somar $2 \%$ da composição modal (Fig. 11B). Porfiroblastos de cianita (10 a 15\%) com dimensóes de até $20 \mathrm{~mm}$ e poiquiloblastos de granada (15\%), com diâmetro de até 15 mm são os demais minerais constituintes deste litotipo.

Em lâmina delgada, verifica-se que a biotita, a exemplo do que foi observado nos gnaisses da FZSill, é avermelhada, o que sugere uma composição mais rica em Ti. Pequenas porçôes dos porfiroblastos de cianita são substituídos por sillimanita neoformada. Os poiquiloblastos de granada, além 

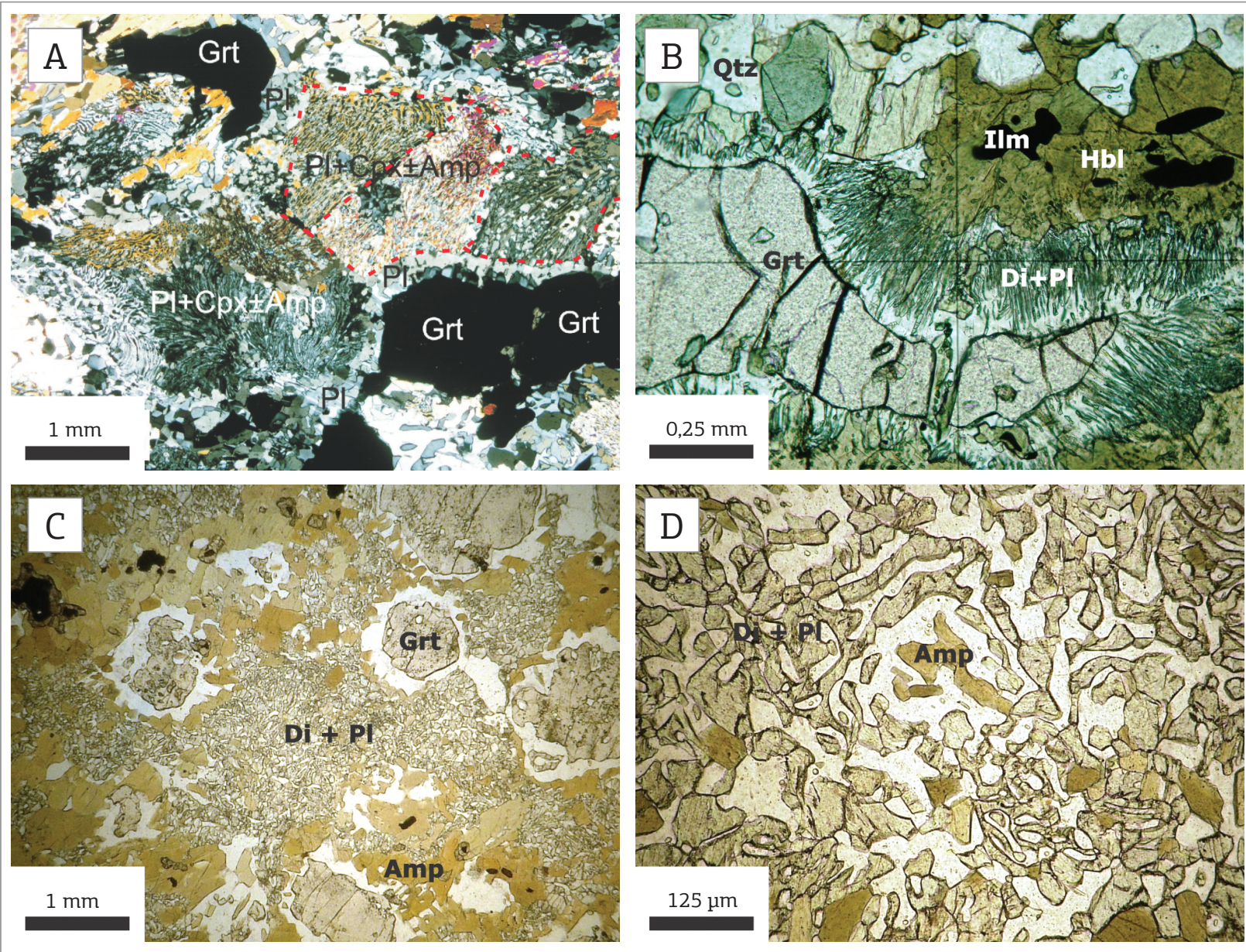

Figura 9. Aspectos microscópicos do retroeclogito de Forquilha. (A) Fotomicrografia à luz polarizada de granada-clinopiroxênio fels. As linhas tracejadas vermelhas marcam simplectitos de plagioclásio e diopsídio que podem representar pseudomorfos de onfacita. Os limites dos pseudomorfos são definidos pela extinção do diopsídio presente nos simplectitos; (B) fotomicrografia de porfuroblasto de granada xenomórfico cercada por simplectito de diopsídio e plagioclásio, que por sua vez, é cercado por corona de anfibólio e ilmenita; (C) fotomicrografia mostrando que os poiquiloblastos de granada são envoltos por coronas de plagioclásio. Entre a matriz, constituída por simplectitos de diopsídio e plagioclásio, e as coronas de plagioclásio está a maior concentração de anfibólio; (D) é comum verificar vermículas de diopsídio substituídas por hornblenda.

de possuírem inclusōes de quartzo, biotita, rutilo e ilmenita, também apresentam sombras de pressão assimétricas preenchidas por quartzo, caracterizando os planos de empurróes com movimento de topo para W e WNW.

As extensas e contínuas rampas de empurrão, com direção N-S, representam característica típica da FZKy, que ao sul da área é marcada por altos do relevo estabelecidos por cristas de quartzitos miloníticos com mais de $1 \mathrm{~km}$ de espessura. Associados às zonas de cavalgamento, também são comuns boudins métricos de rochas cálcio-silicáticas representadas por clinopiroxênio-escapolita-granada-biotita gnaisses (8\% Cpx; 10\% Scp; $15 \%$ Grt; 15\% Bt; $25 \%$ Qtz; 10\% Cal; 10\% Pl; 5\% Kfs; 2\% Rt + Op) e tremolitaclinopiroxênio fels (84\% Cpx; 6\% Tr; 10\% Qtz).

Encaixadas no paragnaisse têm-se ainda lentes quartzografita mármore (5\% Qtz; 10\% Grp; 85\% Cal) e pequenos boudins de granada-clinopiroxênio anfibolito (25\% Grt; $35 \%$ Cpx; 20\% Hbl; 15\% Pl; 2\% Qtz; 1\% Rt; 2\% Cal + $\mathrm{Fe}-\mathrm{Chl}$ ), nos quais os poiquiloblastos de granada são substituídos por Fe-clorita em planos de fraturas paralelos à foliação milonítica. A matriz é constituída de clinopiroxênio subidioblástico disposto em uma textura nematoblástica e substituído por hornblenda nas bordas e ao longo dos planos de clivagem (Figs. 11C e D).

$\mathrm{Na}$ extremidade leste da área, tem-se uma faixa de biotita xisto milonito com porçóes de gnaisse ortoderivado (biotita gnaisse) e gnaisse paraderivado (com cianita ou sillimanita) com lentes de mármores e anfibolitos que constituem uma tectonofácies com estruturação de baixo ângulo. Esta faixa pode representar uma zona de transição para as rochas ígneas pertencentes ao Arco Magmático de Santa Quitéria. 


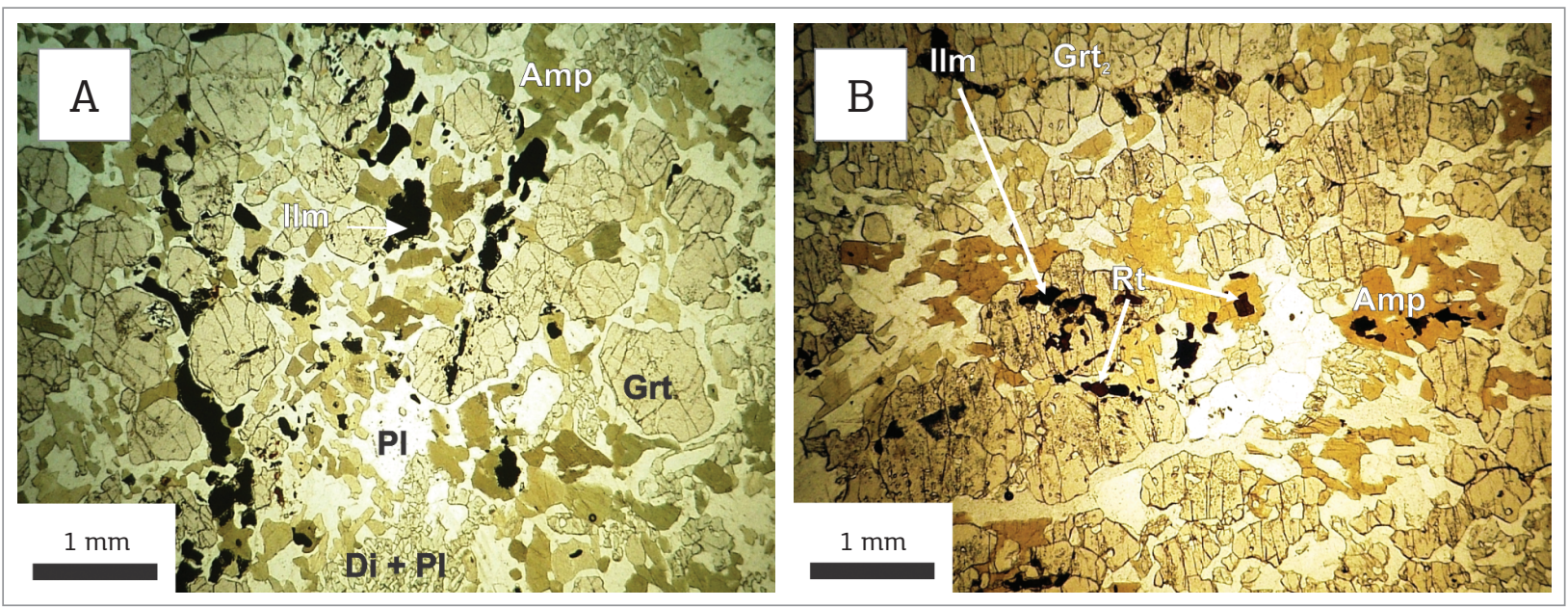

Figura 10. Aspectos microscópicos das porções mais retrógradas do retroeclogito de Forquilha. (A) Fotomicrografia de granada anfibolito. Anfibólio oblitera simplectitos de diopsídio e plagioclásio. Destaque para maior concentração de ilmenita. (B) Fotomicrografia de litotipo onde não há presença de simplectitos de diopsídio e plagioclásio. Há também presença de granadas isentas de coronas de plagioclásio, interpretadas como granadas geradas no retrometamorfismo.
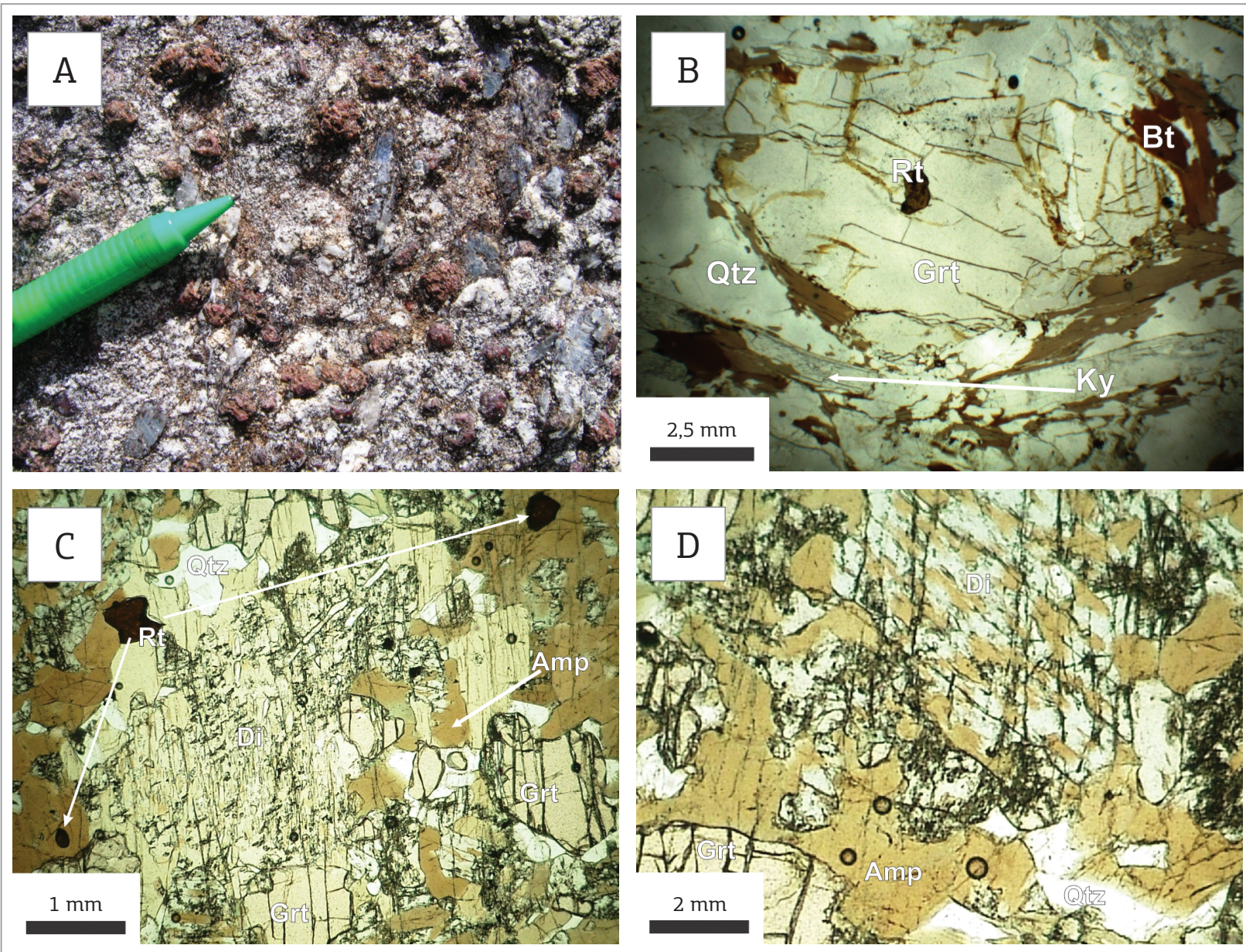

Figura 11. Gnaisse paraderivado da Faixa de gnaisses da Zona da Cianita F e aspectos microscópicos da rocha metamáfica encaixada neste gnaisse. (A) Foto de cianita-granada-biotita gnaisse da Faixa de gnaisses da Zona da Cianita. Porfiroblastos de granada e cianita em matriz gnáissica de granulação grossa composta por quartzo, álcalifeldspato e plagioclásio. (B) Fotomicrografia de cianita-granada-biotita gnaisse da Faixa de gnaisses da Zona da Cianita. Porfiroblasto de granada, com inclusão de rutilo, e porfiroblastos de cianita cercados por biotita e quartzo. (C) e (D) Fotomicrografias de rochas metamáficas inseridas na Faixa de gnaisses da Zona da Cianita. Destaque para a paragênese $\mathrm{Grt}+\mathrm{Di}+\mathrm{Pl}+\mathrm{Amp}+\mathrm{Qtz}+\mathrm{Rt}$ (C). O diopsídio é substituído por anfibólio nas bordas e nos planos de clivagem (D). 


\section{DISCUSSÕES E CONCLUSÕES}

\section{Metamorfismo regional}

A divisão da área em três faixas é baseada nas condiçôes metamórficas identificadas pela associação mineral e inferidas a partir de estudos de rochas análogas. Esta estratégia foi utilizada, pois se identificou que todas as faixas possuem litotipos semelhantes do ponto de vista de seus protólitos, que, em suma, são representados por metapelitos com pequenos boudins de rochas metacarbonáticas e metamáficas. A partir das paragêneses e reaçôes metamórficas identificadas, é possível estabelecer as seguintes consideraçóes, em termos de pressão e temperatura, para as faixas que tectonicamente circundam a FEF:

- Na FZSill, o gnaisse com associação mineral de sillimanita + granada + biotita + quartzo + álcali-feldspato + plagioclásio possui um campo de estabilidade amplo nas grades petrogenéticas para metapelitos no sistema químico KFMASH $\left(\mathrm{K}_{2} \mathrm{O}+\mathrm{FeO}+\mathrm{MgO}+\mathrm{Al}_{2} \mathrm{O}_{3}+\mathrm{SiO}_{2}\right.$ $+\mathrm{H}_{2} \mathrm{O}$ ) e pode indicar condiçóes transicionais entre fácies anfibolito superior e fácies granulito. Os dois corpos de rochas metamáficas inclusos nesta faixa apresentam associaçóes minerais distintas entre si, o que pode ser devido a uma composição diferenciada dos protólitos. Assim tem-se uma associação mineral com granada + anfibólio + plagioclásio + quartzo + titanita \pm diopsídio, e outra composta por diopsídio + anfibólio + plagioclásio \pm titanita, o que estabelece condiçóes de metamorfismo de transição da fácies anfibolito e fácies granulito, com temperaturas mínimas de $675^{\circ} \mathrm{C}$ e pressão superior a 6 kbar (Spear \& Cheney 1989, Powell \& Holland 1990). Epídoto e hornblenda substituindo diopsídio nas bordas e planos de clivagem (Fig. 4E) evidenciam uma reação retrometamórfica em condiçôes transicionais de fácies xisto verde e anfibolito inferior.

- Na FZKy, o gnaisse com a associação mineral de cianita + granada + biotita + quartzo + plagioclásio + álcali-feldspato + rutilo indica condiçóes de pressóes acima de 7 kbar e temperaturas acima da reação de quebra da muscovita, em torno de $680^{\circ} \mathrm{C}$ (O’Brien \& Rötzler 2003, Wei \& Powell 2003). A rocha metamáfica inserida nesta faixa apresenta associação mineral de pico metamórfico caracterizado por granada + diopsídio + plagioclásio + rutilo, o que restringe o metamorfismo a condiçôes mínimas de pressão em torno de $10 \mathrm{kbar}$, acima do limite da curva de desestabilização do ortopiroxênio, e temperaturas superiores a $700^{\circ} \mathrm{C}$ (O’Brien \& Rötzler 2003). O retrometamorfismo é marcado na rocha metamáfica pela presença de hornblenda em simples substituição das bordas e planos de clivagem do diopsídio e, no gnaisse, paraderivado com a simples substituição de cianita por sillimanita.
Para a FEF, o retroeclogito registra uma história do metamorfismo mais completa em relação aos gnaisses encaixantes, algo que é verificado também em outros terrenos de alta e ultra-alta pressão (Heinrich 1982, Coleman \& Wang 1995). Os paragnaisses que compóem esta faixa são fortemente migmatizados com domínio de estruturas nebulíticas e agmáticas, e apresentam a associação mineral de sillimanita (depois de cianita) + granada + álcali-feldspato + quartzo + biotita + rutilo \pm plagioclásio. A ausência de muscovita já sugere condiçōes de metamorfismo superiores a $700^{\circ} \mathrm{C}$, mas são os litotipos augen gnaisse com granada e biotita-granada leucogranito que registram a associação mineral granada + álcali-feldspato + quartzo \pm plagioclásio \pm cianita, e marcam condiçóes de metamorfismo com temperatura próxima a $800^{\circ} \mathrm{C}$ e pressão acima de $10 \mathrm{kbar}$, típico de granulitos de alta pressão que são livres de ortopiroxênio (Gilotti \& Elvevold 2002, Indares, White \& Powell 2008, Guilmette, Indares \& Hébert 2011). Esta associação mineral comumente é formada pela reaçáo (1), que de acordo com Vielzeuf \& Holloway (1988), é importante para a produção substancial de magmas graníticos do tipo $S$, que são segregados de sua fonte, deixando um resíduo composto por aluminossilicato + quartzo + biotita + plagioclásio.

$\mathrm{Bt}+\mathrm{Pl}+\mathrm{Als}+\mathrm{Qtz} \rightarrow \mathrm{Grt}+\mathrm{Kfs}+\mathrm{L}$

Embora Santos et al. (2009b) já tenham estabelecido uma trajetória P-T para o retroeclogito de Forquilha desde a fácies eclogito até a fácies xisto verde em uma trajetória horária, neste trabalho cabe registrar as prováveis reaçóes retrometamórficas, sugeridas com base nas relaçóes petrográficas e em grades petrogenéticas. As reaçôes que seguem foram descritas por Zhao et al. (2001) e Sartini-Rideout, Gilotti \& McClelland. (2009) para retroeclogitos de composição química, descrição petrográfica e ocorrência similar. Desta forma, são estabelecidos três principais estágios de retrometamorfismo e um quarto estágio, ainda que incipiente, em condições de fácies xisto verde.

O primeiro estágio retrometamórfico é marcado por descompressão, com o desenvolvimento de corona de plagioclásio em torno da granada — reaçôes (2) e/ou (3) promovendo o isolamento entre a granada e a onfacita.

$\mathrm{Grt}+\mathrm{Cpx}+\mathrm{Qtz}+\mathrm{H}_{2} \mathrm{O} \rightarrow \mathrm{Pl}+\mathrm{Amp}$

$\mathrm{Grt}+\mathrm{Cpx}+\mathrm{Rt}+\mathrm{Qtz}+\mathrm{H}_{2} \mathrm{O} \rightarrow \mathrm{Amp}+\mathrm{Ilm}+\mathrm{Pl}$

A quebra da onfacita promove a formação de simplectitos de diopsídio e plagioclásio (Mysen \& Griffin 1973), sendo descrita pela reação (4) e caracterizando o segundo estágio de retrometamorfismo. Assim, se estabeleceria a 
associação de granada + diopsídio + plagioclásio + quartzo + rutilo \pm anfibólio, típica de fácies granulito de alta pressão (Pattison 2003), no qual se espera pressôes em torno de $12 \mathrm{kbar}$ e temperaturas superiores a $750^{\circ} \mathrm{C}$.

$\mathrm{Omp} \rightarrow \mathrm{Di}+\mathrm{Pl}$

O terceiro estágio de retrometamorfismo é marcado pelo aparecimento de hornblenda, tanto envolvendo a granada em uma textura coronítica quanto substituindo vermículas de diopsídio - reação (5) —, estabelecendo uma paragênese de transição da fácies granulito para fácies anfibolito. Faixas mais ricas em anfibólio são observadas macroscópica e microscopicamente, o que denota que a entrada de $\mathrm{H}_{2} \mathrm{O}$ no sistema não se deu somente de forma penetrativa, mas também de forma concentrada ao longo de bandas centimétricas.

$\mathrm{Grt}+\mathrm{Di}+\mathrm{Pl}+\mathrm{H}_{2} \mathrm{O} \rightarrow \mathrm{Amp}$

A reação (6) registra o desenvolvimento de litotipos com a paragênese granada + anfibólio + plagioclásio + ilmenita + titanita \pm quartzo, de fácies anfibolito. Esta reação é representativa do desequilíbrio de diopsídio na paragênese, formação de ilmenita e de uma segunda geração de granada nas porçôes mais retrógradas. No entanto, não é possível estabelecer uma ordem cronológica entre as reaçóes (5) e (6), o que sugere que ambas podem ter evoluído simultaneamente durante o terceiro estágio retrometamórfico.

$\mathrm{Grt}+\mathrm{Pl}+\mathrm{Qtz}+\mathrm{H}_{2} \mathrm{O} \rightarrow \mathrm{Grt}_{2}+\mathrm{Pl}(\mathrm{An})+\mathrm{Amp}$

Por fim, algumas fraturas milimétricas são preenchidas por vênulas de composição quartzo-calcítica que favorece em suas imediações a substituição de granada por Feclorita. Outra situação verificada é a formação de actinolita nas clivagens de hornblenda. Ambas as situaçóes representam a incipiente formação de uma associação mineral característica de fácies xisto verde, com temperaturas aproximadas de $400^{\circ} \mathrm{C}$ e pressôes iguais ou inferiores a 4 kbar.

\section{Implicações tectônicas}

Cada faixa litológica individualizada neste trabalho possui uma história diferenciada de metamorfismo. Por conta disto, é razoável admitir que os planos de cavalgamentos, que limitam cada uma delas, são feições estruturais importantes no processo de exumação das rochas da FEF. $\mathrm{O}$ padrão de foliação e lineação mineral mostra uma variação de cavalgamento, de leste para oeste, desde cavalgamentos frontais, na região próxima ao Arco Magmático de Santa Quitéria, fora dos limites da área, a um padrão oblíquo. Esta evolução continuaria com o desenvolvimento posterior de zonas transcorrentes, a exemplo das falhas transcorrentes de Forquilha e Humberto Monte.

De acordo com Cavalcante et al. (2003), as faixas aqui individualizadas como FZSill e a FZKy fazem parte da sequência supracrustal neoproterozoica do Grupo Ceará, mais especificamente, da Unidade Independência, enquanto a FEF estaria inserida em uma unidade paleoproterozoica definida como Complexo Canindé. Isto reforça a importância das estruturas de cavalgamento no processo de exumação e a consequente colocação de unidades basais imbricadas tectonicamente em unidades de cobertura.

Com relação aos aspectos metamórficos, é fato que os gnaisses encaixantes dos corpos de retroeclogito não preservaram uma paragênese de fácies eclogito, possivelmente devido ao intenso retrometamorfismo, o que é recorrente em terrenos com esta característica (Proyer 2003, Peterman, Hacker \& Baxter 2009). Aliado a este fato, nota-se que as bordas dos corpos de retroeclogitos mostram uma evolução retrometamórfica mais intensa em relação às porções mais centrais devido à interação com os fluidos metamórficos, como sugerem as reaçóes (3), (4) e (5), que são promovidas pela entrada de $\mathrm{H}_{2} \mathrm{O}$ no sistema.

Do ponto de vista geotectônico, rochas que estiveram submetidas à fácies eclogito fornecem sustentável argumentação na caracterização de ambientes colisionais e de zonas de subdução. A presença de rochas submetidas a tais condiçôes metamórficas na Província Borborema, em especial no Domínio Ceará Central, possibilita a discussão de modelos relativos à evolução geológica dessa porção da província e a sua correlação com a contraparte africana. Este exercício de correlação entre blocos crustais que formaram a porção oeste do Gondwana foi objeto de trabalhos apresentados por Almeida e Black (1968), Caby, AndreopoulosRenaud e Pin (1989), Castaing et al. (1993), Trompette (1994, 1997), Brito Neves, Van Schmus e Fetter (2002), e outros mais recentes em Pankhurst et al. (2008).

No que diz respeito à porção setentrional da Província Borborema, o Domínio Médio Coreaú e o Domínio Ceará Central são correlacionados com a Faixa Dahomeydes e a porção central do Hoggar na África. O Lineamento Transbrasiliano, que separa os dois domínios da Província Borborema, é relacionado com os lineamentos Kandi e 4050' na África. O Lineamento Senador Pompeu que separa os domínios Ceará Central e Rio Grande do Norte é correlacionado com o Lineamento Ile-Ife.

A definiçâo do batólito Tamboril-Santa Quitéria como constituído por rochas que seriam produto de fusão parcial de uma fonte juvenil e com idades de cristalização neoproterozoica (Fetter et al. 2003) permite correlacionar, ao longo do Lineamento Transbrasiliano - Kandi - Hoggar 
$4^{\circ} 50^{\prime}$, três grandes fragmentos juvenis neoproterozoicos que são, além do Arco Magmático de Santa Quitéria, o Arco Magmático de Goiás (Pimentel et al. 2000) e os complexos graníticos de composição cálcio-alcalina na Faixa do Hoggar, na regiāo de Mali, África (Liégeois, Bertrand \& Black 1987, Caby, Andreopoulos-Renaud \& Pin 1989, Caby 2003). A oeste de Hoggar, as zonas de suturas estão bem caracterizadas pela presença de sequências ofiolíticas desmembradas e na existência de rochas em fácies eclogito (Caby 1994, Jahn, Caby \& Monié 2001). Dados geofísicos reafirmam este fato (Lesquer, Beltrao \& De Abreu 1984). $\mathrm{Na}$ Faixa Brasília, essa zona pode ser marcada por rochas metamáficas de alto grau (Della Giustina et al. 2009). Na Província Borborema, até então, apenas anomalias geofísicas sugeriam uma provável zona de sutura encoberta por rochas da Bacia do Parnaíba (Lesquer, Beltrao \& De Abreu 1984), o que mantinha no âmbito das possibilidades a conexão dos oceanos Pharusiano e Goianides, como já ressaltado por Fetter et al. (2003) e Santos et al. (2008b).

O retroeclogito de Forquilha está a leste do Lineamento Transbrasiliano (Domínio Ceará Central), ca. 15 quilômetros a oeste do Arco Magmático de Santa Quitéria, e pode representar o registro de uma suposta subdução no sentido ESE, seguida de colisão continental. Os dados geoquímicos dos retroeclogitos de Forquilha definem uma afinidade tholeítica do tipo N-MORB e IAT (Amaral, Santos \& Wernick 2011), o que reforça a ideia de possíveis resquícios de uma subdução oceânica.

O mapeamento em escala de detalhe e as observaçóes petrográficas permitem-nos estabelecer as seguintes conclusóes a respeito do retroeclogito de Forquilha:

- Dentre os principais mecanismos de exumação é provável que as falhas de cavalgamento que separam os diferentes domínios metamórficos aqui diferenciados, sejam importantes estruturas associadas à exumação de rochas de profundidades superiores a $50 \mathrm{~km}$, posicionando-as sobre rochas de grau metamórfico inferior (rochas da FZSill e da FZKy). As relaçôes de campo e as evidências petrográficas indicam intenso retrometamorfismo e sugerem uma exumaçáo lenta das rochas da FEF. Este retrometamorfismo foi favorecido pela infiltração de fluidos controlados por estruturas geradas a partir desta exumação.

- O retrometamorfismo ocorreu de forma heterogênea nos corpos de retroeclogitos, sendo muito mais intenso nas regiôes de bordas e porçóes com proeminente foliação milonítica, podendo ser caracterizado por quatro estágios principais. O primeiro e segundo associados à descompressão, que promoveu a desestabilização da paragênese de fácies eclogito para a fácies granulito de alta pressão, e os demais foram favorecidos pela gradual e crescente entrada de $\mathrm{H}_{2} \mathrm{O}$ no sistema, promovendo a estabilidade de uma paragênese de fácies anfibolito $(\mathrm{Grt}+\mathrm{Hbl}+\mathrm{Pl} \pm \mathrm{Cpx} \pm \mathrm{Qtz})$, e depois a incipiente formação de minerais típicos de fácies xisto verde.

\section{AGRADECIMENTOS}

Ao Conselho Nacional de Desenvolvimento Científico e Tecnológico/Instituto Nacional de Tecnologia-Estudos Tectônicos (CNPq/INCT-ET) (Processo no 573713/2008-1) e à Fundação de Amparo à Pesquisa do Estado de São Paulo (FAPESP) (Processo $n^{\circ}$ 07/58.535-6), pelo suporte financeiro ao trabalho de mapeamento, preparação de amostras e análises em microscopia eletrônica de varredura. Agradecemos também as bolsas $\mathrm{CNPq}$ aos alunos do Programa de Pós-graduação em Geociências da Universidade Estadual de Campinas.

\section{REFERÊNCIAS}

Almeida C.N., Beurlen H., Guimarães I.P., Sampaio A.S. 1997. Highpressure metamorphosed $\mathrm{Fe}$-Ti ore-hosting island-arc tholeiites at Itatuba (Paraíba) as an indication of a Proterozoic suture in the Pajeú-Paraíba Fold Belt, Borborema Province, northeastern Brazil. International Geology Review, 39(7):589-608

Almeida C.N., Guimarães I.P., Beurlen H., Topitsch W.M. 2009a. Caracterização geoquímica de rochas metamáficas e metaultramáficas da Faixa Pajeú-Paraíba, Província Borborema NE Brasil. Anuário do Instituto de Geociências - UFRJ, 32(1):46-61.

Almeida C.N., Guimarães I.P., Beurlen H., Topitsch W.M., Ferrer D.M.M. 2009b. Evidências de metamorfismo de alta pressão na faixa de dobramentos Pajeú-Paraíba, Província Borborema, nordeste do Brasil: petrografia e química mineral de rochas metamáficas. Revista Brasileira de Geociências, 39(3):421-434.
Almeida F.F.M., Black R. 1968. Geological comparison of northeastern South American and Western Africa. Anais da Acadêmia Brasileira de Ciências, 40:317-319.

Almeida F.F.M., Hasui Y., Brito Neves B.B., Fuck R.A. 1981. Brazilian structural provinces: an introduction. Earth Science Reviews, 17(1-2):1-29.

Amaral W.S. \& Santos T.J.S. 2008. Airborne geophysical and tectonics of the Ceará Central Domain, eastern region of the Santa Quitéria Magmatic Arc, Borborema Province. Revista Brasileira de Geofísica, 26(4):527-542.

Amaral W.S. 2010. Análise geoquímica, geocronológica e termobarométrica das rochas de alto grau metamórfico adjacentes ao Arco Magmático de Santa Quitéria, NW da Província Borborema. 
Tese de Doutorado, Instituto de Geociências, Universidade Estadual de Campinas, Campinas, 256 p.

Amaral W.S., Santos T.J.S. \& Wernick, E. 2011. Occurrence and geochemistry of metamafic rocks from the Forquilha Eclogite Zone, Central Ceará (NE Brazil): geodynamic implications. Geological Journal, 46(2-3):137-155.

Ancelmi M.F. 2011. Metamorfismo e estudo de proveniência, baseado em $\mathrm{U}-\mathrm{Pb}$ em zircões detríticos e isótopos de $\mathrm{Nd}$, das rochas metassedimentares da Faixa Eclogítica de Forquilha (CE), NW da Província Borborema. Dissertação de Mestrado, Instituto de Geociências, Universidade Estadual de Campinas, Campinas, 88 p.

Araújo C.E.G., Cordani U.G., Basei M.A.S., Castro N.A., Sato K., Sproesser W.M. 2012. U-Pb detrital zircon provenance of metasedimentary rocks from the Ceará Central and Médio Coreaú Domains, Borborema Province, NE-Brazil: Tectonic implications for a long-lived Neoproterozoic active continental margin. Precambrian Research, 206-207:36-51

Arthaud M.H., Caby R., Fuck R.A., Dantas E.L., Parente C.V. 2008. Geology of the northern Borborema Province, NE Brazil and its correlation with Nigeria, NW Africa. In: Pankhurst R.J., Trouw R.A.J., Brito Neves B.B., de Wit M.J. (eds.). West Gondwana: PreCenozoic Correlation Across the South Atlantic Region. Geological Society, London, Special Publications, 294:49-67.

Bard J.P. 1985. Microtextures of igneous and metamorphic rocks. Petrology and Structural Geology Series, Volume 1, Springer, $264 \mathrm{p}$.

Beurlen H. \& Villarroel H.S. 1990. Petrografia de duas ocorrências de provável eclogito em Bodocó e Floresta no Estado de Pernambuco, Brasil. Revista Brasileira de Geociências, 20:111-121.

Beurlen H., Silva Filho A.F., Guimarães I.P., Brito S.B. 1992. Proterozoic c-type eclogites hosting unusual $\mathrm{Ti}-\mathrm{Fe} \pm \mathrm{Cr} \pm \mathrm{Cu}$ mineralization in northeastern Brazil. Precambrian Research, 58(1-4):195-214.

Brewer T.S., Storey C., Parrish R., Temperley S., Windley B.F. 2003. Grenvillian age decompression of eclogites in the GlenelgAttadale Inlier, NW Scotland. Journal of the Geological Society, London, 160(4):565-574.

Brito Neves B.B., Santos E.J. \& Van Schmus W.R. 2000. Tectonic history of the Borborema Province. In: Cordani U.G., Milani E.J., Thomaz Filho A., Campos D.A. (eds.). Tectonic Evolution of South America. 31th International Geological Congress, Rio de Janeiro, Brazil, p. 151-182.

Brito Neves B.B., Van Schmus W.R. \& Fetter A.H. 2002. Northwestern Africa-North-eastern Brazil. Major tectonic links and correlation problems. Journal of African Earth Sciences, 34(3-4):275-278.

Caby R. \& Arthaud M.H. 1986. Major Precambrian nappes of the Brazilian belt, Ceará, northeast Brazil. Geology, 14(10):871.

Caby R. 1994. Precambrian coesite from northern Mali: first record and implications for plate tectonics in the trans-Saharan segment of the Pan-African belt. European Journal of Mineralogy, 6:235-244

Caby R. 2003. Terrane assembly and geodynamic evolution of central-western Hoggar: a synthesis. Journal of African Earth Sciences, 37(3-4):133-159.

Caby R., Andreopoulos-Renaud U. \& Pin C. 1989. Late Proterozoic arc-continent and continent-continent collision in the panAfrican trans-Saharan belt of Mali. Canadian Journal of Earth Sciences, 26(6):1136-1146.
Campos Neto M.C. \& Caby, R. 1999. Neoproterozoic high-pressure metamorphism and tectonic constraint from the nappe system south of the São Francisco Craton, southeast Brazil. Precambrian Research, 97(1-2):3-26.

Castaing C., Triboulet C., Feybesse J.L., Chèvremont P. 1993. Tectonometamorphic evolution of Ghana, Togo and Benin in the light of the Pan-African/Brasiliano orogeny. Tectonophysics, 218(4):323-342

Castro N.A. 2004. Evolução geológica proterozóica da região entre Madalena e Taperuaba, domínio tectônico Ceará Central (Província Borborema). Tese de Doutorado, Instituto de Geociências, Universidade de São Paulo, São Paulo, 221 p.

Cavalcante J.C., Vasconcelos A.M., Medeiros M.F., Paiva I.P., Gomes F.E.M., Cavalcante S.M., Melo A.C.R., Duarte Neto V.C., Benevides H.C. 2003. Mapa geológico do Estado do Ceará. Escala 1:500.000, CPRM, Fortaleza, CE.

Choudhuri A., Fiori A.P., Winters A.A.M., Bettencourt J.S., Rodrigues J.E. 1978. A note on small bodies of eclogite as inclusions in high grade gneisses north of Pouso Alegre, Minas Gerais. Revista Brasileira de Geociências, 8:63-68.

Coleman R.G. \& Wang, X. 1995. Overview of the geology and tectonics of UHPM. In: Coleman R.G. \& Wang, X. (eds.). Ultrahigh Pressure Metamorphism. Cambridge University Press, New York, p. 1-32.

Della Giustina M.E.S., Oliveira C.G., Pimentel M.M., Bühn B. 2009. Neoproterozoic magmatism and high-grade metamorphism in the Goiás Massif: New LA-MC-ICMPS U-Pb and Sm-Nd data and implications for collisional history of the Brasília Belt. Precambrian Research, 172(1-2):67-79.

Faryad S.W., Klápová H. \& Nosál L. 2010. Mechanism of formation of atoll garnet during high-pressure metamorphism. Mineralogical Magazine, 74(1):111-126.

Fetter A.H. 1999. U-Pb and Sm-Nd geochronological constraints on the crustal framework and geologic history of Ceará State, NW Borborema Province, NE Brazil: Implications for the assembly of Gondwana. PhD Dissertation, Department of Geology, University of Kansas, $164 \mathrm{p}$.

Fetter A.H., Santos T.J.S., Van Schmus W.R., Hackspacher P.C., Brito Neves B.B., Arthaud M.H., Nogueira Neto J.A., Wernicka E. 2003. Evidence for Neoproterozoic continental arc magmatism in the Santa Quitéria Batholith of Ceará State, NW Borborema Province, NE Brazil: Implications for the assembly of West Gondwana. Gondwana Research, 6(2):265-273.

Fetter A.H., Van Schmus W.R., Santos T.J.S., Nogueira Neto J.A., Arthaud M.H. 2000. U-Pb and Sm-Nd geochronological constraints on the crustal evolution and basement architecture of Ceará State, NW Borborema Province, NE Brazil: implications for the existence of the Paleoproterozoic Supercontinent "Atlantica". Revista Brasileira de Geociências, 30(1):102-106.

Garcia, M.G.M. \& Arthaud M.H. 2004. Caracterização de trajetórias P-T em nappes brasilianas: região de Boa Viagem/ Madalena - Ceará Central (NE Brasil). Revista de Geologia - UFC, 17(2):173-191

Gilotti J.A. \& Elvevold S. 2002. Extensional exhumation of a high-pressure granulite terrane in Payer Land, Greenland Caledonides: structural, petrologic, and geochronologic evidence from metapelites. Canadian Journal of Earth Sciences, 39(8):1169-1187.

Guillot S., Mahéo G., de Sigoyer J., Hattori K.H., Pêcher A. 2008. Tethyan and Indian subduction viewed from the Himalayan high- to ultrahigh-pressure metamorphic rocks. Tectonophysics, 451(1-4):225-241 
Guilmette C., Indares A. \& Hébert R. 2011. High-pressure anatectic paragneisses from the Namche Barwa, Eastern Himalayan Syntaxis: Textural evidence for partial melting, phase equilibria modeling and tectonic implications. Lithos, 124(1-2):66-81.

Heinrich C.A. 1982. Kyanite-eclogite to amphibolite fades evolution of hydrous mafic and pelitic rocks, Adula nappe, Central Alps. Contributions to Mineralogy and Petrology, 81(1):30-38.

Indares A., White R.V. \& Powell R. 2008. Phase equilibria modelling of kyanite-bearing anatectic paragneisses from the central Grenville Province. Journal of Metamorphic Geology, 26(8):815-836.

Jahn B.M., Caby R. \& Monié P. 2001. The oldest UHP eclogites of the World: age of UHP metamorphism, nature of protoliths and tectonic implications. Chemical Geology, 178(1-4):143-158.

Lesquer A., Beltrao J.F. \& De Abreu F.A.M. 1984. Proterozoic links between Northeastern Brazil and West Africa: A plate tectonic model based on gravity data. Tectonophysics, 110(1-2):9-26.

Liégeois J.P., Bertrand J.M. \& Black R. 1987. The subduction- and collision-related Pan-African composite batholith of the Adrar des Iforas (Mali): a review. Geological Journal, 22 (S2):185-211.

Martins G., Oliveira E.P. \& Lafon J.M. 2009. The Algodões amphibolite-tonalite gneiss sequence, Borborema Province, NE Brazil: Geochemical and geochronological evidence for Palaeoproterozoic accretion of oceanic plateau/back-arc basalts and adakitic plutons. Gondwana Research, 15(1):71-85.

Mattos I. 2005. Geologia, petrografia, geoquímica, comportamento fisicoquímico e alterabilidade das rochas ornamentais do stock granítico Serra do Barriga, Sobral (CE). Tese de Doutorado, IGCE, Universidade Estadual Paulista "Júlio de Mesquita Filho", Rio Claro, 260 p.

Mysen B. \& Griffin W.L. 1973. Pyroxene stoichiometry and the breakdown of omphacite. American Mineralogist, 58:60-63.

O’Brien P.J. \& Rötzler J. 2003. High-pressure granulites: formation, recovery of peak conditions and implications for tectonics. Journal of Metamorphic Geology, 21(1):3-20.

Oliveira D.C. \& Mohriak W.U. 2003. Jaibaras trough: an important element in the early tectonic evolution of the Parnaiba interior sag basin, Northern Brazil. Marine and Petroleum Geology, 20(3-4):351-383.

Pankhurst R.J., Trouw R.A.J., Brito Neves B.B., de Wit M.J. 2008. West Gondwana: pre-Cenozoic correlations across the South Atlantic region, Geological Society, London, Special Publications, $294,430 \mathrm{p}$.

Pattison D.R.M. 2003. Petrogenetic significance of orthopyroxenefree garnet + clinopyroxene + plagioclase +- quartz-bearing metabasites with respect to the amphibolite and granulite facies. Journal of Metamorphic Geology, 21(1):21-34.

Peterman E.M., Hacker B.R. \& Baxter, E.F. 2009. Phase transformations of continental crust during subduction and exhumation: Western Gneiss Region, Norway. European Journal of Mineralogy, 21(6):1097-1118.

Pimentel M.M., Fuck R.A., Jost H., Ferreira Filho, C.F., Araujo S.M. 2000. The basement of the Brasilia Fold Belt and the Goiás Magmatic Arc. In: Cordani U.G., Milani E.J., Thomaz-Filho A., Campos D.A. (eds.). Tectonic Evolution of South America. 31th International Geological Congress, Rio de Janeiro, Brazil, p. 195-229.

Powell R. \& Holland T. 1990. Calculated mineral equilibria in the pelite system, KFMASH $\left(\mathrm{K}_{2} \mathrm{O}-\mathrm{FeO}-\mathrm{MgO}-\mathrm{Al}_{2} \mathrm{O}_{3}-\mathrm{SiO}_{2}-\mathrm{H}_{2} \mathrm{O}\right)$. American Mineralogist, 75(3-4):367-380.

Proyer A. 2003. Metamorphism of pelites in NKFMASH - a new petrogenetic grid with implications for the preservation of high-pressure mineral assemblages during exhumation. Journal of Metamorphic Geology, 21(5):493-509.

Reno B.L., Brown M., Kobayashi K., Nakamura E., Piccoli P.M., Trouw R.A.J. 2009. Eclogite-high-pressure granulite metamorphism records early collision in West Gondwana: new data from the Southern Brasilia Belt, Brazil. Journal of the Geological Society. London, 166(6):1013-1032

Sajeev K., Windley B.F., Connolly J.A.D., Kon Y. 2009. Retrogressed eclogite $\left(20 \mathrm{kbar}, 1020^{\circ} \mathrm{C}\right)$ from the Neoproterozoic Palghat-Cauvery suture zone, southern India. Precambrian Research, 171(1-4):23-36.

Santos T.J.S., Fette, A.H., Van Schmus W.R., Hackspacher P.C. 2009a. Evidence for 2.35 to $2.30 \mathrm{Ga}$ juvenile crustal growth in the northwest Borborema Province, NE Brazil. In: Reddy S.M., Mazunder R., Evans D.A.D., Collins A.S. (eds.). Palaeoproterozoic Supercontinents and Global Evolution. Geological Society, London, Special Publication, 323:271-281

Santos T.J.S., Fetter A.H., Hackspacher P.C., Van Schmus W.R., Nogueira Neto J.A. 2008a. Neoproterozoic tectonic and magmatic episodes in the NW sector of Borborema Province, NE Brazil, during assembly of Western Gondwana. Journal of South American Earth Sciences, 25(3): 271-284.

Santos T.J.S., Fetter A.H., Nogueira Neto J.A. 2008b. Comparisons between the northwestern Borborema Province, NE Brazil, and the southwestern Pharusian Dahomey Belt, SW Central Africa. In: Pankhurst R.J., Trouw R.A.J., Brito Neves B.B., de Wit M.J. (eds.). West Gondwana: Pre-Cenozoic Correlation Across the South Atlantic Region. Geological Society, London, Special Publication, 294:101-120.

Santos T.J.S., Garcia M.G.M., Amaral W.S., Caby R., Wernick E., Arthaud M.H., Dantas E.L., Santosh M. 2009b. Relics of eclogite facies assemblages in the Ceará Central Domain, NW Borborema Province, NE Brazil: Implications for the assembly of West Gondwana. Gondwana Research, 15(3-4):454-470.

Santos T.J.S., Nogueira Neto J.A., Fetter A.H., Hackspacher P.C. 2001. Petrografia e litogeoquímica das rochas do embasamento cristalino da região de Granja-CE. Revista de Geologia - UFC, 14(1):33-48.

Santos T.J.S., Souza G.M., Queiroz H.B., Nogueira Neto J.A., Parente C.V. 2002. Tafrogênese estateriana no embasamento paleoproterozóico do NW da Província Borborema. Uma abordagem petrográfica, geoquímica e geocronológica. Anais do XLI Congresso Brasileiro de Geologia, João Pessoa. p. 337.

Sartini-Rideout C., Gilotti J.A. \& McClelland W.C. 2009. Reaction progress and timing of retrogression of eclogite-facies rocks, Danmarkshavn, North-East Greenland Caledonides. European Journal of Mineralogy, 21(6):1149-1172

Silva L.C., Armstrong R.A., Pimentel M.M., Scandolara J., Ramgrab G., Wildner W., Angelim L.A.A., Vasconcelos A.M., Rizzoto G., Quadros M.L.E.S., Sander A., Rosa A.N.Z. 2002. Reavaliação da evolução geológica em terrenos pré-cambrianos brasileiros com base em novos dados U-Pb SHRIMP, Parte III: províncias Borborema, Mantiqueira Meridional e Rio Negro-Juruena. Revista Brasileira de Geociências, 32(4):529-544.

Song S., Zhang L., Niu Y., Su L., Song B., Liu D., 2006. Evolution from oceanic subduction to continental collision: a case study from the Northern Tibetan Plateau based on geochemical and geochronological data. Journal of Petrology, 47(3):435-455.

Spear F.S. \& Cheney J.T. 1989. A petrogenetic grid for pelitic schists in the system $\mathrm{SiO}_{2}-\mathrm{Al}_{2} \mathrm{O}_{3}-\mathrm{FeO}-\mathrm{MgO}-\mathrm{K}_{2} \mathrm{O}-\mathrm{H}_{2} \mathrm{O}$. Contributions to Mineralogy and Petrology, 101(2):149-164

Trompette R. 1994. Geology of Western Gondwana, Pan-African Brasiliano aggregation of South America and Africa. Brookfield, A. A. Balkema, Rotterdam, 350 p. 
Trompette R. 1997. Neoproterozoic ( 600 Ma) aggregation of Western Gondwana: a tentative scenario. Precambrian Research, 82(1-2):101-112

Vauchez A., Neves S.P., Caby R., Corsini M., Egydio-Silva M., Arthaud M.H., Amaro V. 1995. The Borborema shear zone system, NE Brazil. Journal of South American Earth Sciences, 8(3-4):247-266.

Vielzeuf D. \& Holloway J.R., 1988. Experimental determination of the fluid-absent melting relations in the pelitic system. Contributions to Mineralogy and Petrology, 98(3):257-276.

Vilela L.G.G. 2000. Petrografia, geotermobarometria e evolução metamórfica de granulitos básicos de alta pressão e rochas transicionais para fácies eclogito na região de Lima Duarte, MG. Dissertação de Mestrado, Instituto de Geociências, Universidade de São Paulo, São Paulo, 180 p.
Wei C. \& Powell R. 2003. Phase relations in high-pressure metapelites in the system KFMASH $\left(\mathrm{K}_{2} \mathrm{O}-\mathrm{FeO}-\mathrm{MgO}-\mathrm{Al}_{2} \mathrm{O}_{3}-\mathrm{SiO}_{2}-\mathrm{H}_{2} \mathrm{O}\right)$ with application to natural rocks. Contributions to Mineralogy and Petrology, 145(3):301-315.

Will T.M. \& Schmädicke E. 2001. A first find of retrogressed eclogites in the Odenwald Crystalline Complex, Mid-German Crystalline Rise, Germany: evidence for a so far unrecognised high-pressure metamorphism in the Central Variscides. Lithos, 59(3):109-125.

Zhao G.C., Cawood P.A., Wilde S.A., Lu L. 2001. High-pressure granulites (retrograded eclogites) from the Hengshan Complex, North China Craton: Petrology and tectonic implications. Journal of Petrology, 42(6):1141-1170.

Arquivo digital disponível on-line no site www.sbgeo.org.br 